Portland State University

PDXScholar

Spring 7-9-2014

\title{
The Impact of Economic Integration within the European Union as a Factor in Conflict Transformation and Peace-Building
}

John Umo Ette

Portland State University

Follow this and additional works at: https://pdxscholar.library.pdx.edu/open_access_etds

Part of the International Relations Commons, and the Peace and Conflict Studies Commons Let us know how access to this document benefits you.

Recommended Citation

Ette, John Umo, "The Impact of Economic Integration within the European Union as a Factor in Conflict Transformation and Peace-Building" (2014). Dissertations and Theses. Paper 1893.

https://doi.org/10.15760/etd.1892

This Thesis is brought to you for free and open access. It has been accepted for inclusion in Dissertations and Theses by an authorized administrator of PDXScholar. Please contact us if we can make this document more accessible: pdxscholar@pdx.edu. 
The Impact of Economic Integration within the European Union as a Factor in Conflict Transformation and Peace-Building

by

John Umo Ette

A thesis submitted in partial fulfillment of the requirements for the degree of

\author{
Master of Science \\ in \\ Conflict Resolution
}

Thesis Committee:

Harry Anastasiou, Chair

Rachel Cunliffe

Robert Gould

Portland State University

2014 


\begin{abstract}
This study examines economic integration within the European Union as a factor in conflict transformation and peace-building. European responses to causes of frequent conflict and wars after the end of WWII focused on the search for peace, economic cooperation and prosperity. This thesis will focus on three elements: economic interdependence, the expansion of the free market, and economic integration. In-depth examination of these factors reveals that economic interdependence or the exchange of goods and services across inter-state and international boundaries only, is not sufficient to bring peace among states. Economic interdependence may reduce the impact of war, but cannot maintain sustainable peace. Unfair competition fanned by economic nationalism was a strong obstacle to free trade in Europe in the early 19th century. In the 21 st century, the expansion of the free trade, with increased understanding has enhanced reduction in interstate conflicts. However, free trade, in and of itself does not constitute a strong factor for a sustainable peace. Free trade may encourage democracy, but the expansion of free trade coupled with interdependence, does not bring sustainable peace. The EU has successfully established sustainable peace through economic integration-the creation of the single market that establish freedom of movement, people, goods, services; and a single currency that facilitates easy transactions. The single market also abolished tariffs and custom duties. By and large, economic integration within the EU has been successful in creating sustainable peace because economic interdependence, and the expansion of the free market have been combined with political integration by building democratic institutions at the intergovernmental and transnational levels.
\end{abstract}




\section{TABLE OF CONTENTS}

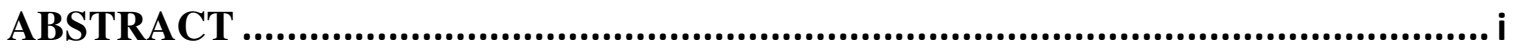

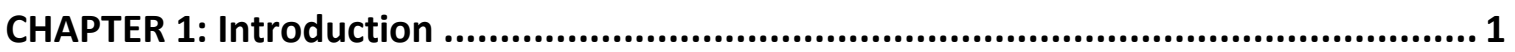

CHAPTER 2: Literature Review: Explanation of Terms and Concepts ....................... 14

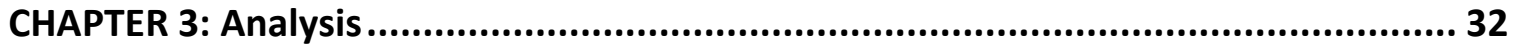

CHAPTER 4: The Political Dimensions of EU Integration ......................................... 46

CHAPTER 5: The EU Network Commerce: A Model of Integration ........................... 60

CHAPTER 6: Concluding Observations ............................................................. 71

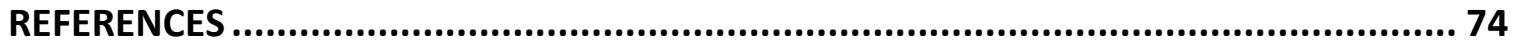




\section{CHAPTER 1: Introduction}

The impact of wars in Europe during the $19^{\text {th }}$ and first half of the 20th century left indelible memories for future generations. Those who survived the wars, as well as succeeding generations, learned a lesson and vowed to abolish war and establish structures that encourage peace, unity, security, and prosperity. The foundation of lasting peace was laid with strong economic activities such as trade, improvement in agriculture, industry, infrastructure, and provision of essential services. Along with economic activities, political and economic institutions were also vital in maintaining peace and security and help in transforming European societies in a way that soothes and heals the wounds of war and conflict.

The historical background of this thesis reveals war and conflict in Europe which led to massive devastation of human life and the economy. Having experienced war in my childhood in Nigeria (though not of a similar degree and magnitude as WWI and WWII), I have been inspired by the European experience to focus my study on the transformative agents and factors that ushered in peace and development. The EU is the agent of that peace and development. As a little child in elementary school, I experienced, and felt the impact of civil war in Nigeria. Memories of fear, brutal killings, trauma, and war planes that dropped bombs are still fresh in my mind many years after the war. I was one of those children in refugee camps who suffered hunger, malnutrition, abuse and neglect. Like many other children, I lost my childhood, but luckily, I survived the war. During the war, schools were closed and I felt so sad because school was an essential part of my growing up. Many children roamed the streets in search of anything in the form of food. There was scarcity of food and many children died of hunger, insecurity and poor health 
conditions caused by the filthy and unsafe environment during the war. A number of children, especially the orphans, succumbed to child labor and slavery, while others were forced to become child soldiers. There was hunger and unemployment everywhere as efforts of the government were focused on managing the war.

My experience is a reflection of what happens to millions of children, women and men in conflict areas and places ravaged by war in all parts of the world. If this happened to me in a civil war which lasted for about three years, even worse must have happened to children and people in Europe during WWI and WWII which lasted for many years.

An important factor that contributes to my interest in this study is the significance of external help that brought the conflict in Nigeria to an end. As the European reconstruction effort was strongly enhanced by the United States (US), the efforts and contributions of international organizations and countries like the US, the United Kingdom (UK), and the International Red-Cross played a significant role in bringing the civil war in Nigeria to an end. External relief agencies from the US and Europe provided substantial assistance for rehabilitation and reconstruction after the war. Gradually, new infrastructures were designed and constructed, the economy was transformed and eventually, peace came along with development.

The impact of any war, be it civil or international, is always devastating with prolonged physical and mental health consequences. However, the impact of wars and conflicts in Europe were alarming because of the historical perspective of Europe with its belligerent past that was full of fierce, diverse, and tangled economic and political interests that accumulated beginning from the $14^{\text {th }}$ century. 
By the $19^{\text {th }}$ century, Europe was the most powerful, economically prosperous, and technologically advanced continent in the world. However, this economic prosperity and super-power status were attained through violence, negative nationalistic ideologies, imperialism, and abuse of human rights. A huge investment in militarism encouraged inter-state and international wars. In the course of world history, European nations have been constantly at war with each other more than with other nations of the world (McCormick, 2005; Rachman, 2004). Urwin notes that “The nineteenth century witnessed an ever-increasing imperialist competition among European states, an assertion of the supremacy of national autarky and intensification of competition that eventually culminated in World War 1" (1991, p.3).

Constant wars and insecurity led to the logic of forming alliances to balance power among European nations (Rachman, 2004). More often, broken alliances led to protracted wars; for example, the Thirty Years War, the Franco-German Wars, the First World War (WWI), the Second World War (WWII), the Cold War and many other internal wars. Most of these wars were fought to prevent any one European nation from rising to hegemony (Leonard, 2005). As such, the struggle for military supremacy dominated the politics of the nations of Europe, while the economy, democracy, human values, peace and freedom of minorities and less powerful societies were ignored. Worse still, Darwin's concept of the 'survival of the fittest' and the struggle for supremacy encouraged the power-play of domination and expansion of the sphere of influence for national prestige and resource control.

The era of European political, economic, and cultural dominance in the world came to an abrupt end with WWII (Urwin, 1991). In 1945, Hitler was defeated and Germany 
was in ruins; France was humiliated and its work-force reduced by half. Britain was bankrupt and on the verge of losing her empire; Spain was a backward, isolated dictatorship, while the Central and Eastern European Countries (CEEC) such as Czechoslovakia, Hungary, Poland, and Romania had been absorbed into the former Soviet Empire (Rachman, 2004). Political alliances were forged for security reasons without firm commitment to sustainable economic cooperation and growth. Worse still, the "absolutist and self-centered approaches of ethno-nationalism, that were prevalent in nearly all European states, made it increasingly difficult for European nations to establish inter-national, inter-societal inter-dependencies which fosters economic, technological growth and development" (Anastasiou, 2007, p.3). Consequently, the impact of the global economic depression on the first half of the twentieth century was alarming. It began with the collapse of the stock market in the United States in 1929. The ripple effects of this single event were felt worldwide. This single economic disaster exposed the evils of ethno-nationalism, and the negative dynamic patterns of selfcenteredness led to hatred, and war in full force (Anastasiou, 2007).

As Europe advanced into the mid-twentieth century, it began to witness a tremendous transformation. It began by abandoning and demolishing the old ideologies of ethnicnationalism, as well as imperialism. It recognized the independence of former colonies in Third World countries. In the decade that followed, there was no more fear of a rising Germany or France because all the countries of Europe collaborated and formed themselves into a network that is bound together by democratically set laws and regulations. Instead of competition in building alliances, or building and storing weapons of war, "their interests are now defined through mutual vulnerability, pooled sovereignty 
and transparency" (Leonard, 2005, p. 27). These mutual interests have been established through constant efforts, cooperation, and in signing various treaties that have resulted in the emergence of the European Union (EU) (Leonard, 2005; McCormick, 2005; Rifkin, 2004). Nobody would have predicted that Europe was at the beginning of a new golden age (Rachman, 2004). Presently, a continent that has been devastated by wars can now boast of lasting peace for the last sixty-five years. A continent that was in economic ruin after WWII in 1945 is now prosperous as never before. (Even as one takes into account the impact of the global recession since 2008, the EU remained relatively stable and free of war).

Before the Cold War, up to 1989, Europe was divided by the iron curtain; now, its citizens are enjoying free movements and common political institutions within the twenty-seven countries that stretch from the Atlantic coast of Portugal in the south, to the borders of Russia in the north (Rachman, 2004, p.3).

As early as 1942, Europe could list only four proper democracies, now the continent is almost entirely democratic.

\section{Focus and Rationale of the Study}

This study investigates the ways economic phenomena impact human well-being, as well as conditions leading to war or peace. The challenge is to ascertain under what conditions economic forces become catalysts for conflict or peace. As conflict and competition cannot be far removed from an analysis of cooperation and interdependence, similarly, conflict in the pre-EU Europe cannot be separated from economic issues. Competition per se, is not a bad thing in the real world, but unfair and unbalanced competition creates undue challenges and conflict. As stated by Lairson and Skidmore, “...competition among firms or nations is possible only in a context in which the rules 
for trade, investment, and profit making have been created and are maintained through international cooperation" (1997, p.165).

In $19^{\text {th }}$ century Europe, competition and conflict were inherent elements of capitalism because in a situation where the competing parties operated in the spirit of power alliances instead of laid down rules for trade, investment, and profit making, the stronger and more powerful faction(s) often took it all. International rivalry over, at least, the past two centuries has been caught up in the efforts of capitalist firms to secure markets and resources (Lairson \& Skidmore, 1997). In testimony to this, the two great wars (WWI and WWII) of the twentieth century began as conflicts among capitalist's states, but also absorbed the Soviet Union. In the later part of the $19^{\text {th }}$ century, fears abounded regarding the ability of Europe to compete in the world economy. Apparently, this was because many factors such as nationalism and forming of alliances between rival power blocks which undermined cooperation also served to enhance competition and conflict (Lairson \& Skidmore). Smith (1993) has noted that other factors such as authoritarian leaders contributed to usurp national sentiments, and impede economic cooperation. But, the strongest factors were self-centered approaches of ethno-centric nationalism that were prevalent in all European states. As stated by Anastasiou, "In the context of rampant nationalism, economic interdependence was in fact one of the central factors that drew the nation states of pre-1945 Europe into war" (2007, p.3). Economic interdependence by itself was not a bad thing. But without clear rules for cooperation and competition, conflict brewed. In the light of this, Anastasiou also asserts that, "In the absence of multilateral cooperation among nation-states, economic interdependency became a curse not a blessing" (2007, p. 3). Conversely, under conditions of cooperation and leveling of 
the playing field, economic conditions would become catalysts for peace. Under conditions where there is regulated competition, absence of protectionism, decline in tariffs, or nontariff barriers (NTBs), the probability of conflict would be drastically reduced. This study seeks to examine economic integration within the EU as a factor in conflict transformation and peace building. The study contributes to the conflict resolution knowledge base, and attempts to generate an interest in this new and special supranational organization (the EU) by looking deeply into its efforts, resources and potential in maintaining peace and democracy on the continent of Europe and promoting peace in the world. EU integration has not been widely identified as a peace system in literature in the field of Peace Studies and Conflict Resolution. As indicated by Anastasiou, (2007), "Barash and Webel's Peace Studies, one of the most comprehensive university textbooks in the field, makes only scanty references to the EU” (p.1).

This study is compelling because it attempts to focus attention on the conflict resolution approach that has been fashioned by the EU through economic integration which has enabled Europe to maintain peace in the continent for more than six decades. Positive peace is very difficult to achieve, and the EU appears to have made a breakthrough in this respect. The EU appears to demonstrate that more cooperation and not cutthroat competition is the way to establish enduring peace. It also appears to demonstrate that peace is achieved by building structures and institutions that will help to sustain peace and development.

To many Europeans in the post-World War era, ethnic nationalism has been regarded as an evil that is associated with hatred, conflict, and war. Peace was elusive in the era of nationalism in Europe. The fact that the EU has been able to stem the tide of ethnic 
nationalism, and replace it with peace, democracy, socio-economic development, and rising standards of living-especially among its poorer member states, makes this study unique and compelling. According to Merino, "The EU is a system of institutionalized conflict resolution" (Merino, 2007, p. 28). In confirmation of Merino's assertion, the Nobel Peace Prize earned by the EU in 2012 is a strong testimony in support of the EU's long sustained efforts in European integration and peace building.

\section{Research Question}

The present study answers one key question, and that is: How does economic integration contribute to peace in Europe through the framework of the European Union? In other words, how did European nations go from economic rivalry and fighting each other, to 'coming together' to make decisions and set up an integrated economic system and institutional framework that enables them to establish a sustainable peace? In this study, three hypotheses are addressed: (1) Economic interdependence is the way to establish enduring peace and prosperity; (2) Expansion of the free market leads to peace.

(3) The general hypothesis, therefore, is that, democratically and jointly managed economic integration will lead to sustainable peace and economic prosperity. In the first hypothesis, economic interdependence is the process in which different countries depend on each other for trade by exchanging goods and services through export and import arrangements. In the second hypothesis, the expansion of the free market involves removing all forms of barriers, tariffs, and all forms of protection such as state aid from interstate and international trade relations. It involves proper regulation and fair competition for all member states. 
Economic integration, in the context of this study, involves making concessions, collaborating, pooling human, economic, and political resources together. It involves mutual transactions, risks, and investments that could be evaluated in relation to tangible goals and measureable outcomes (Byrne, Matic, \& Fissuh, 2009). The evaluation of the role of economic integration naturally would prompt a quantitative approach as the factors may be defined in measurable economic and monetary terms. However, in this context, a number of factors that are involved in integration are those that are related to social, economic and political conditions of daily life. Many involve subjective elements that are not really accommodated through the exclusive use of the quantitative approach. In general terms, therefore, the difference between these two approaches is that a quantitative approach collects empirical data, while the qualitative approach relates meaning (Green, Murphy, \& Snyder, 2000).

A qualitative approach will be applied in this study. As already stated, there is limited literature in the field of conflict resolution and peace studies on EU integration. The shortage of relevant literature poses a problem associated with studying a supranational organization (like the EU) that has never previously existed. As noted by Leonard, (2005), Rifkin, (2005) and McCormick, (2004), the EU is an organization that continues to evolve in its structure, and policies. Hence, its transformation, like its enlargement process, cannot be determined at the moment. In view of these difficulties, this study will employ a qualitative method in order to tap into subjective and structural meanings and generate tentative new insights or hypothesis. The primary variables are economic integration within the EU, conflict transformation and peace building. The analysis will seek to explore whether there is a positive relationship between economic integration and 
peace. The qualitative approach will provide a meaningful explanation for the continued cooperation among various EU member states and their interests. By so doing, positive measurable outcomes will explain clearly the satisfaction each member state derives from transferring a measure of sovereignty to EU level as a condition for participating in the EU's decision making process.

Data will not be collected by interviewing human subjects. Facts and vital information will be based on secondary literature and analysis of EU documents and declarations to provide insight into general analysis of the EU's involvement in resolving conflicts within and beyond its domain. The analysis will obtain data from the opinions and experiences of citizens in the EU 27 (EC, 2006), especially in the Eurobarometer, a regularly measurable public opinion research program conducted by the EU on a wide variety of issues relating to European integration (EC. 2006). Some of the issues and policies include the single market, enlargement, European institutions, democracy and human rights, monetary policy, security, mobility of people and consumer rights, among others. Data analysis consists of facts, figures and themes that emerge from the study readings, stories embedded in texts and readings such as the single market survey and the Eurobarometer were identified and discussed in the study.

\section{Summary of Chapters}

Chapter one has presented the logic of war and conflict that were prevalent in the European society of the pre-WWII era. It focused on the rise and fall of the European hegemony and the emergence of the EU as an integrating institution in Europe. Unfair and unregulated competition and economic interdependence without relevant institutions to manage them encouraged incessant wars and conflicts. This state of chaos and 
confusion impacted the economy to the point of disintegration in the decades leading to WWII. In chapter two, a review of literature and explanation of concepts presents an overview of relevant issues, theories, concepts and controversies. Key terms are defined and explained in the context of the study. These include peace, democracy, and conflict transformation. Others include competition or competitiveness, economic integration, economic interdependence, and shared sovereignty. The concepts of economic integration and competition are also explained. These are important factors in economic integration. Relevant terms and theories are also discussed in this chapter. These include peace theory, conflict theory, and conflict transformation theory.

The analysis in chapter three sheds light on specific terms that further elaborate, compares, contrasts, and answers the research question - under what conditions economic forces become catalysts for peace. Some of these conditions are found to be economic interdependence, expansion of the free market, economic integration, sustainable peace and prosperity. The analysis emphasizes the role of institutions in combination with factors such as economic interdependence, and the free market in building sustainable peace and prosperity.

Chapter four shows that, political integration is necessary for a complete economic integration to occur. Economic policies established by treaties, such as the single market (which promotes and requires freedoms, such as movement of people, labor, goods, and services), and the single currency are essential to economic integration and prosperity. It emphasizes the importance of political structures such as EU laws and regulatory organs that are best suited to managing economic factors and institutions. It further explains that economic and political institutions such as the European Parliament, and the European 
Court of Justice, are established by treaties, and are important in making and enforcing rules and regulations that maintain law and order in member states. It is also the responsibility of EU institutions to make decisions, develop policy instruments regarding commerce, transportation, agriculture, and many other social, economic, and political sectors that strengthens economic integration.

In the context of the EU economic integration, 'network commerce' in chapter five involves pooling economic and political resources together for the progress of all member states. Network, from the vantage of EU economic integration, is the mechanism that moves economic integration successfully. Networking is an important strategy in economic integration in that, it enables EU citizens to learn new innovations, exchange ideas and knowledge, and invest together. The chapter explains the reduction of economic disparities and how the program serves to support less developed and developed areas in member states. It shows that fair competition, enhanced by regulation, removal of trade barriers and by maintaining standards of production of goods and services is a strong attribute of a network that supports economic integration. The SM is a major land mark of EU economic integration also explained in this chapter. This chapter delineates the progress and achievement of the EU economic activities in member states. It also shows that, in an environment with fairly competitive rules, economic transactions might become catalysts for peace. The analysis comprises statistics that illustrate the remarkable achievements of companies, corporations, and business ventures in enhancing growth of the EU economy compared to other advanced countries. This marked economic progress is significant in the context of this study, in that economic prosperity translates into improved standards of living, peace, and well- 
being of the citizens in member states. Finally, in chapter six, concluding observations review the hypotheses and remarks on the focus and rationale of the study, and the research question. It comments on limitations of the study and provides recommendations for future study. 


\section{CHAPTER 2: Literature Review: Explanation of Terms and Concepts}

\section{Relevant Terms and Theories}

This chapter consists of the overview of relevant issues, theories, concepts and

controversies. Key terms are defined and explained in the context of the study. These include peace, democracy, and conflict transformation. Others include competition or competitiveness, economic integration, economic interdependence, and shared sovereignty.

\section{Peace Theory}

It is important to define the terms "peace" and "transformation" within the context of this study. In common terms, peace is understood as the absence of conflict, or hostility, and the existence of healthy or newly healed interpersonal or international relationships (Barash, 2002). It is also a quality used to describe a society or a relationship that operates harmoniously. A peaceful condition may be determined by the absence of those factors that lead to war and conflict. For instance, potential causes of non-peace include insecurity, social injustice, economic inequality, political and religious radicalism, acute racism and nationalism (Bonisch, 1981)

Galtung (1995) has done extensive work in the area of world peace and has taken the definition of peace beyond the relatively meaningless and simple absence of war. Galtung's understanding of peace links it with the orientation to a "positive peace" which aims at socio-economic development and other factors that are necessary to bring about a stable and progressive society (1995). For Galtung, peace is not a state, but a process; the final point of which can only be reached if other stages have been successfully mastered, and related activities focused on issues pertaining to peace (Bonisch, 1981). Peace has also been understood as "a process and permanent attempt to 
contravene the different dimensions of force" (Jahn, 1979, p. 23). Picht (1975)

characterizes peace as a global problem and links his definition to other global problems. In his analysis on resolving global conflict, Picht proposed five factors that might bring solution to war and establish world peace. These factor are: (i) an effective burden sharing between nations to prove that the hungry two thirds of mankind would have their subsistence life guaranteed economically; (ii) a supra-national management of the world's food resources; (iii) a supra-national management of the existing raw materials of all nations of the world; (iv) a disarmament and arms control comprehensively managed in such a way that it would be technically impossible to wage a world war; and (v) the establishment of a supra-national institution that has the power to effectively tackle and reduce global pollution, especially the pollution of the oceans (Picht, p. 5051). Picht appears to present some essential factors that correlate human needs with peace and human existence. According to Bonisch, "The preservation of peace is the most important global problem since a nuclear war might mean the end of civilization" (p. 167). This is the crux of the matter and the EU has already taken the initiative in implementing some of the factors suggested by Picht, most especially, the task of integrating different European states into a supranational institution for mutual economic cooperation, better standard of living, and lasting peace.

Historically, war and peace have played important roles in the thinking and acting of man. Specifically, the disastrous effects of war to well-being, health, and existence have forced individuals, people, and nations to take preventive and adaptive precaution (Bonisch, 1981). The effects of war have been known and felt right from ancient times, but it has been difficult to explain exactly what peace is, and how it could be gained 
(Bonisch). One thing is very clear, and that is, many people have the desire to live in peace. Moreover, people maintain an understanding that social progress and personal happiness are only possible under peaceful conditions (Shocking \& Anderson, 1960). Peace has not only been regarded as the absence of war, or a state of none war, but has also been identified as a condition that enhances the production of material well-being, social and economic progress. The fact that peace time has always been associated with progress and prosperity compelled Greek philosophers to characterized peace as "the greatest good" (Bonisch, p 165). Having been accorded the value of greatest good, peace, therefore, became a desirable social ideal; it symbolizes prevention of disasters and destructions as well as maintenance and development of human achievements. Peace is accorded the character of a superior value in many communities, societies, organizations, and nations even in modern times.

In the feudal era, the issue of war and peace was given considerable attention. For example, the bourgeois thinkers (the progressive class) focused their interest in humanitarian and enlightenment issues (Engel, 1962). As Bonisch has noted, Kant opposed the prevailing social evils of the feudal era, including serfdom and wars (1981). Although the Bourgeoisie ruthlessly criticized war, the external peace promised by the enlightenment changed into an endless war of conquest (Engel).

\section{Democratic Peace Theory}

It is widely argued in international relations and conflict theories that democratic nations rarely go to war against each other. But, according to Barash (2002), democracies are no more peaceful than other forms of government. However, one thing is certain; they are unlikely to go to war against each other. In his essay on "Perpetual 
Peace", Kant (1795) explained that a constitutional republic was one of the many conditions for a perpetual peace. In simple terms, Kant meant that the majority of people would never vote to go to war unless a 'just war' was waged in self-defense. It follows, therefore, that if all nations of the world were republics there would be no more war because there would be no aggressors (Kant, 1795). Many reasons have been advanced in the social sciences for why peace loving nations have decided to avoid war. Proponents of democratic peace theory believe that democracies share three features of political relations ingrained in liberal norms (Doyle, 1996). These features, when combined, promote the absence of war between liberal and non-liberal states. First, at the democratic level, liberals introduce caution into the affairs of state. For example, caution may involve the opinion of the citizenry being taken into consideration before military action can be undertaken knowing quite well that, since citizens would have to bear the cost of the war, their support is necessary. Secondly, at the international level, the consensus among liberals involves maintaining the rights of states. This mutual relationship is marked by respecting principles of non-intervention. Thirdly, at the transnational level, relations are marked by the spirit of commerce which leads states to have mutual interest in the welfare of other states as trading partners (Johnson, 1998). Johnson goes further to explain that it is the international level factor that best explains why the democratic peace position is limited to inter-liberal state relations. One primary reason that supports this claim is the consent factor. In true democratic states, relations between the populace and the government are assumed to be characterized by consent. But in non-democratic (or non-liberal) states relations between the government and the populace are assumed to be characterized by coercion (John \& O’Leary, 2007). 
Moreover, democracies assume other democracies to be just, therefore, deserving of accommodation. In contrast, none democracies are assumed to be unjust and, therefore, are regarded with deep suspicion.

The EU has gone beyond democratic peace theory. The opportunity for membership is extended to European states purely by their consent and not by the use of force or coercion (Leonard, 2005; Rifkin, 2004). Leonard goes on to state that the "European Union is a laboratory for reinventing democracy" (p. 92). The EU creates a "public space' to debate and resolve pressing problems, where political majorities can emerge, and solutions at the European level can motivate EU citizens. This practice makes an immense contribution to peace at the local, national, and regional levels.

\section{Modern Democracy-The EU Version}

The EU has taken democracy into a modern advanced level. After World War II, “democracy gained firm footing, triumphing over centuries of monarchs, dictators, fascism, religious strife and the most barbaric of internecine wars" (Hill, 2010, p. 240). Democracy has many advantages. Because of its numerous achievements in providing much needed resources and infrastructures to member countries and citizens, the EU is highly credited for "harnessing capitalism to create wealth" (p. 240). As a result, people have had jobs to support their families. Through proper management of its institutions and functionaries, the EU is able to "foster ecological sustainability and a new type of leadership based on regional networks of peace and prosperity partnerships" (p. 240241). Gartzke, has argued that if the main intent of the policy of democratization is to bring international peace, then the process of introducing such democracy should be directed with caution (2005). Instead of focusing first on democracy, Gartzke, proposed 
that it is "more effective to promote peace through the spread of free markets to bolster the move to democracy" (p. 38). The EU appears to have accomplished its successes by first maintaining peace through the process of the single market. In an attempt to move Europe from the pre-war conflict ridden era, to the modern era, the EU has "forged political institutions that foster inclusiveness, participation, authentic representation, multi-party democracy, and majoritarian policy based on consensus view points..." (p. 241). According to Hill, the EU's concept of 'consensus' means the "efforts to find common ground among diverse and even opposing forces" (p. 241). Other significant concepts of EU democracy include political dialogue; break down of partisan defenses, representative democracy - incorporating all ethnicities, religion, languages, geographic regions, and even climate zones. The EU is also an expert in applying modern day 'town halls' as an exciting new instrument in the toolbox of democracy (Hill).

\section{Conflict Transformation Theory}

Conflict transformation is another important perspective on the peacemaking venture (Curle, 1971; Rupsinghe, 1995). Transformation, according to social scientists, moves through certain predictable phases: reconstruction of social organizations, changes in relationships, and changes in communication patterns (Boulding, 1962; Coleman, 1956). Galtung (1996) has given a clear explanation of core concepts of transformation. He asserts that conflicts have both life-affirming and life-destroying aspects. Once formed from contradictions in the structure of society, these conflicts become manifest in attitudes and behavior. In a dynamic pattern, conflicts undergo a variety of transformational processes such as "articulation or dis-articulation, complexification or simplification, polarization or depolarization, escalation or de-escalation" (Galtung, p. 
90). Galtung's approach appears to be compatible with that of Curle's who did his study two decades earlier. Curle, (1971) illustrated his work with asymmetric relationships. In his approach, he traced how asymmetric relationships could be transformed through a shift from unbalanced to balanced relationships, achieved through a process of conscientisation, confrontation, negotiation and development (Curle, 1971).

With a strong interest and focus, Lederach (1995) picked up and built on Curle's ideas. He maintains that transformation is assumed in terms of "a shift in relationship", for example, "a shift from mutually destructive, unstable, and harmful expressions towards a mutually beneficial and cooperative basis" (p.42). From the perspective of system and structure, transformation might help to bring about change which involves building on the energy and impact of the conflict itself in a positive manner. For example, the 'earthquake diplomacy' between Greece and Turkey in 1997 was a remarkable transforming event that led to a significant change in the Greek-Turk relationship (Anastasiou, 2008a). In such a situation, conflict became "a transforming agent for systematic change" (Lederach, p. 42). From the non-violent theorist's perspective, non-violent campaigns can transform conflict by detaching the props sustaining it. For instance, a community may resist land reform and on the other hand, encourage mass cultivation on the disputed area in order to provide more food for the community.

On the whole, transformation suggests a dynamic understanding (a learning process) that conflict can move in destructive or constructive directions. Furthermore, it provides "an effort to maximize the achievement of constructive, mutually beneficial processes and outcomes" (Lederach, p. 46). The EU is a shining example of an organization, in 
modern times, that has transformed conflict into constructive and mutually beneficial processes.

\section{Relevant Concepts:}

\section{The Concept of Competitiveness}

A discussion of the concept of competitiveness is significant for understanding the economic relationships among states. Lairsen and Skidmore have affirmed that the world economy functions successfully with a well-structured international cooperation (1997). They go on to say that "competition and conflict are inherent elements of capitalism" (1997, p.165). Therefore, productive power and military power linked to capitalism generate an enormous prize to be won by sovereign states as domestic political power frequently rests on economic growth and dynamism (Lairson \& Skidmore, 1997). Deutsch and Coleman (2000) clearly define some basic assumptions that arise from the theory of cooperation and competition. Cooperation or cooperative relations (those with goals aiming at positive interdependence) show some of these positive characteristics: effective communication, friendliness, helpfulness, coordination of efforts, and feelings of agreement with ideas of others (similarities in beliefs and values). In addition, willingness to enhance the other's power and defining conflicting interests to be solved by collaborative efforts are very important (Deutsch, et al, 2000).

In contrast, competitive process shows predominantly negative characteristics. Communication is impaired (as the conflicting parties seek to gain advantage by misleading the other). There is obstructiveness and lack of helpfulness, duplication of efforts, gross disagreement, and the threat to enhance their power and reduce the power of others. Above all, there is the use of coercive tactics and threat of violence to resolve conflict in a competitive process (Deutsch, et al, 2000). The concepts of cooperation and 
competition are relevant to this study in that fierce competition dominated economic (and political) life of the period leading to the Second World War (WWII) in Europe. Efforts at cooperation began in the aftermath of WWII in Europe and gradually led to stronger cooperative ideas and organizations-which later translate to integration in the form of the European Community and presently, the European Union (Urwin, 1991).

A surge in economic nationalism became a big threat to the European Community. In the EU era, "competition policy has been a success story but has come under attack as a result of economic nationalism, itself a byproduct of globalization" (Euromove, 2011, p. 2). Although this practice might be useful to a country in the short-term, history has shown that in the long-term, state aid and protectionism weakens rather than strengthen economies (Euromove). The conflict surrounding international economic relations could be traced back to history more than half a century ago. Lairson and Skidmore distinguished three periods reflecting the trend of international competition. The first period covered the early 1930s, a period "when competitive impulses overwhelmed competitive efforts" (1979, p.419). During this period, the strain caused by the Great Depression forced nations to construct "Stiff protectionist barriers and formed economic blocks in a bid to preserve domestic production and employment" (p.420). Consequently, protectionism led to a terrible and painful reduction in world trade and increase political tensions.

The next period extended from 1947 to 1973. This period, according to Lairson and Skidmore, witnessed serious and fruitful efforts in cooperation. During this period, different institutions and rules were created to help manage the growth of economic interdependence. However, this did not ensure fair competition, though "protectionist 
barriers fell dramatically, levels of international trade and investment increased and expanded rapidly during the 1960 s" (1979, p. 420). These trends are attributed to two factors: (1) "the close security relationships forged among the United States, Western Europe, and Japan during the Cold War" (p. 420). Additionally, political leaders could have learned their lessons, basically, from the biting hardships of the Great Depression of the 1930s.

A third period extended from 1973 and beyond. Europe witnessed a relaxed and balanced attitude in cooperation and competition in the area of international political economy (Lairson \& Skidmore, 1979). Beginning from this period, a significant level of interdependence was experienced though perfect competition and cooperation was not attained. By and large, competition did not spin out of control leading to mutually destructive conflict as had been the situation during the early part of the 19th century. More than a century ago, when Europe was the pioneer of the industrial revolution, she advanced to prominence. Europe had no competitor from beyond its borders (The Economist, 1992). As time went by, Europe began to face stiff competition and rivals from American and Japanese firms, especially in the area of fast growing high technology industries. It seems surprising that Europe - the pioneer of the industrial revolution - experienced such a steep decline in international trade while efficient rivals overtook Europe's first place. The reason was obvious. Europe was divided and the European market was also divided (The Economist). The divided European market "prevented European companies from spreading their spending on research and development, and had forced them to spend their fortune tailoring their products to meet national standards" (p. 50). This divisive stance of European companies in various 
European states was a big barrier towards effective competition with strong American and Japanese counterparts. For Europeans, unfair competition also manifested in form of various national norms, in that, a lot of time and efforts were wasted in trying to meet various national norms. This caused European companies to fail to compete effectively with American and Japanese companies -each working as a team (Leonard, 2010; The Economist). The Economist also notes that, "European companies on the other hand, found it hard to think of Europe as one." (p. 51). It also blames European governments in that, "By nurturing nationalized companies, they damaged European competitiveness" (The Economist, p.50). However, the decline in European markets was not irreversible. The Economist records that, after significant development in the steel industries, it bounced back followed by other industries (1992).

\section{The Concept of Economic Integration}

In practice, the process of economic integration comprises measures that effectively discourage some forms of discrimination. It is different from economic cooperation which entails actions aimed at reducing discrimination (Nelson \& Stubb, 2003). An example is international agreement on trade policies which maintain international cooperation. There are many different degrees of integration. For instance, "the removal of trade barriers is an act of economic integration" (Nelsen \& Stubb, p.180). Suranovic defines integration as "Any type of arrangement in which countries agree to coordinate their trade, fiscal, and/or monetary policies..." (1998, p. 1). The most obvious example of economic integration is the EU which has "evolved from a collection of autarkical nations to become a fully integrated economic unit" (Holden, 2003, p.1). Nelsen and Stubb, as well as Suranovic appear to agree that economic integration involves a number 
of factors. These include a free trade area, a customs union, a common market, and an economic union. A free trade area entails that tariff (and other activities involving restrictions) between the participating member states are abolished. However, each country retains its own tariffs against non-EU members. Holden also maintains that formal economic integration takes place in stages, beginning with the lowering and removal of barriers to trade and culminates in the creation of an economic union.

Economic integration within the EU could be summarized in four stages: free trade agreements, customs union, the common market, and the economic union (Holden, 2003; Leonard, 2010; McCormick 2004; Suranovic, 1998). According to Holden, the first level of formal economic integration is the establishment of free trade agreements (FTAs). Once FTAs are in place, they eliminate import tariffs and import quotas between member states and signatory countries. In many cases, such as in the North American Free Trade Agreements (NAFTA), FTAs also include formal mechanisms to resolve trade disputes. The Customs Union (CU) builds on a free trade area by removing internal barriers to trade; it also requires that participating nations harmonize their external trade policy. Harmonizing trade policy requires establishing a common external tariff (CET) and import quotas on products entering the EU from third party countries (Holden, 2003; Nelsen \& Stubb, 2003). Holden also maintains that in order to gain the benefits of a customs union, member states would have to surrender some degree of policy freedom specifically, the ability to set independent trade policy (Holden).

The Common Market (CM) is a factor that represents a major step towards significant economic integration. In addition to containing the provisions of a customs union, the common market removes all barriers to the mobility of people, capital and 
other resources within the area of operation. Furthermore, it eliminates non-tariff barriers to trade, such as regulatory treatment of product standards (Holden, 2003; Lairson \& Skidmore, 1997; Nelsen \& Stubb, 2003). Holden goes further to state that "The principal advantage in establishing a common market is the expected gains in economic efficiency" (p. 2). Apparently, this is a successful manifestation in the EU as indicated by unfettered mobility that has enhanced labor and capital to more easily respond to economic signals within the common market. As a result, there is a more efficient allocation of resources within the EU.

Last but not least, is the economic union (EU). Economic union is "the deepest form of economic integration" (Holden, 2003). When combined with the common market, it fulfills the need to harmonize a number of key policy areas. According to Holden, “economic union requires formally coordinated monetary and fiscal policies, as well as labor market, regional development, transportation, and industrial policies" (p.2). The use of a common currency and a unified monetary policy are other factors of the economic union. These help to eliminate exchange rate disparities and improve the functioning of an economic union by allowing trade to flow efficiently without being affected by exchange rates.

As part of the economic union, a supra-national institution is required for a complete economic integration to occur (Holden, 2003, Suranovic, 1998; Urwin, 1991). In the European Union, for example, supra-national institutions regulate commerce within the union to ensure a uniform application of the rules. It is also the responsibility of supranational agency to carry out some fiscal spending responsibilities (Suranovic, 1998). 


\section{Integration as Multilateral Cooperation and Economic Interdependence}

There is much discussion in the literature on the definition of the concept of international integration. Deutsch and Coleman define integration as "the attainment, within a territory, of a 'sense of community' and of institutions and practices strong enough and wide spread enough to assure, for a 'long' time, dependable expectations of 'peaceful change' among its population" (1957, p. 22). Deutsch and Coleman also assert that, when a group of people or states have been integrated in this way, they constitute a security community.

Funk and Wagnalls, define integration as "...bringing together into whole; to unify" (1971, p. 338). Why is the process of bringing together into a whole important? Why is Europe interested in that process? In terms of the EU, economic integration involves the development of a transactional society with increased contacts and mutual awareness among individuals from different national settings (Nye, 1972). Jacob and Teune (1964), state that “... political integration generally implies... a feeling of identity and self-awareness" (p. 4). This is one of the goals of the EU- to foster the identity of Europe and mutual cooperation.

Furthermore, "the essence of the integration relationship is seen as a collective action to promote mutual interests, for the issues of mutual interests in the areas of health, education, monetary policy, trade, to advance- peace and democracy." (Nye, 1972). In order to determine the extent to which problem specification, decision, and policy application are carried out successfully, the EU, in concert with other governments (of nations states) through regular diplomatic channels, ad hoc procedures, has set up 
intergovernmental institutions to enhance the process; for instance, the EU Commission, the Council of Ministers, and the Parliament (1972).

According to Gartzke and Lupu, interdependence involves trade, development, open financial markets and monetary policy coordination (2011). Gartzke and Lupu go further to explain that interdependence reduces conflict by: (i) "aligning states' interests, which gives them less to fight over, (ii) providing a means of peacefully securing resources ; and (iii) allowing states to foresee the cost of fighting, which facilitates bargaining and compromise" ( p. 166).

With regard to cooperation, Urwin notes that, "the post-war economic problems of the continent demand a substantial element of very close cooperation" (1992, p. 27). What was lacking was multilateral cooperation among nation states. A situation that saw the advent of a viable and multilateral economic interdependency began with the production of coal and steel-two raw materials for war became united under a common organization, the European Coal and Steel Community (ECSC) (Gazelles \& Hoffman, 1999). This was the first step towards integration; and it involved six major European nations; France, Germany, Italy, the Netherlands, Luxemburg, and the Benelux country (McCormick, 2005).

\section{Shared Sovereignty and EU Integration}

Sovereignty in relation to governance is usually defined as the right to hold and exercise authority (McCormick, 2005). According to McCormick, sovereignty normally lies in the hands of the person or institution that exercises control over the territory (2005). For example, in democratic systems of governance, this usually means the national legislature. McCormick further explained that, in a democracy, the sovereign 
may not answer to any higher authority, but only the people because it is the will of the people that decides where power lies (2005). Basically, sovereign power is usually exercised by the institution that the people elect, but naturally, sovereignty lies with the people (McCormick, 2005). In Spinelli's vision of the European integration, his goal, as with most federalists, was a new Europe composed of individual states that had ceded their sovereignty to common democratic institutions (Nelsen \& Stubb, 2003).

\section{Perspectives and Developments: Observations from the EU Integration Process}

The most impressive developments have been obvious from the functions of the European Community (Nye, 1972). A number of other observers (Angell, 1969; Kindleberger, 1970; Lindberger, 1971; Jacob \& Tueune, 1964) have reported on positive effects of integration relationships. Observers have also seen the impact multinational enterprises have had on regional economic communities such as peace, regional cooperation, democracy as well as basic human needs and issues such as health, education, monetary policy, trade (Lindberg, 1971) and many others. One advantage of economic integration is the ability of multinational enterprises to see beyond national boundaries with helping to make the treaty of Rome an economic reality (Klineberger, 1970). European integration is an on-going process that has many phases. It embraces the emerging of interests and the entering upon systematic cooperation between governments on a permanent basis. Jacob and Tueune, state that "the essence of the integration relationship is seen as a collective action to promote mutual interests" (1964, p. 5). Integration involves the coming together of actors to perform a task in a problem situation and their mutual adjustments while performing the task (Schokking \& Anderson, 1960). Integration will come fully into effect if the actors are able to continue 
relationships under mutually accepted rules. For example, if they are able to keep competition under control and to resolve tensions. The actors or partners have to agree and adopt common rules by which they would govern their future conduct. It also involves mutual adjustment while complying with these rules. For the EU, integration takes place under circumstances of continuous social, economic, and political change both within the European area and other parts of the world. The test of integration is that, the process continues in order with negotiation; even while the rules are being adhered to, rule-making may continue (Lairson \& Skidmore, 1997). At the level of the European institutions, these elements have been evident in the negotiations of the European Coal and Steel Community (ECSC). In the case of European integration, the actors in the ECSC, are primarily the six governments of (France, Italy and Spain, Germany, Belgium, and the Benelux) joined by the treaty. Also, the community is an actor in its own right, operating through its several organs. These organs include the European commission, the Council of Ministers, the European parliament, the Court of Justice, to mention the few that work to maintain responsibilities, interests and values of the union and its member states.

In an attempt to adequately address the issue of integration, Schokking and Anderson argue that, "The integration of economic interests is hardly possible without some degree of social integration" (1960, p. 387). Similarly, when values and interests are focused on economic integration, (as in the case of the EU), some degree of political integration also takes place. However, "peaceful political integration can be realized only if, and when economic, social, and cultural interests have reached a high measure of solidarity" (Schokking \& Anderson, 1960, p. 387). Also, Jacob and Teune, (1964), state that, 
"political integration generally implies a relationship of community...a feeling of identity and self-awareness" (p. 4).

It is doubtful whether the integration process in Europe could have evolved under peace time conditions. In other words, if Europe had not been involved in constant wars and conflicts, perhaps the incentive to integrate would have been lost. In one sense, Europe is making a strong and lasting effort not to repeat the attempt that Hitler made to enforce political unification by military means and to impose integration by the dominance of a single party, supported by bayonets, guns, and bombers (Schokking \& Anderson, 1960). In the same manner as Hitler, the former Soviet bloc, in contempt of freedom, forcibly imposed political and economic unification in order to speed up communist integration (Leonard, 2010; Schokking \& Anderson, 1960). The impact of the Cold War, in Europe, America, and other parts of the world cannot be denied by history. The EU is doing the reverse to bring about integration. Integration within the EU is marked by the prevalence of voluntary action and conditions of peace among the countries involved. EU members have chosen to join the union without any form of coercion. 


\section{CHAPTER 3: Analysis}

In light of the preceding context, the following analysis addresses relevant authors whose works have a bearing on assessing the hypotheses of the present thesis.

\section{Hypothesis 1: Economic Interdependence is the Way to Establish Enduring Peace and Prosperity.}

The validity of this hypothesis must be examined in the light of arguments raised by liberal trade theorists and political scientists who attempted to explain why interdependence failed to de-escalate WWI during the first half of the twentieth century, and WWII by mid-twentieth century. First, some political scientists have argued that WWI occurred because economic integration failed to maintain peace (Gartzke \& Lupu, 2011). On the other hand, liberal trade theory maintains that "wars are inhibited by the exchange of wealth across international borders" (2011). This theory is confirmed by the 'no barrier to trade' policy of the EU single market. Furthermore, critics of the liberal trade theory argue that, if economic interdependence had failed to stop the conflict leading to WW1, then it might not be a reliable tool to encourage interstates peace. These critics were also skeptical on the failure of economic integration to bring peace in Europe at the dawn of the twentieth century (1914-1918).

This argument, once again brings in the question: Does economic interdependence bring peace? (Gladstone, 2007). From the affirmative point of view, it could be argued that WWI was not a compelling failure for liberal trade theory, and that economic interdependence did not fail in 1914 (Gartzke \& Lupu, 2011). According to this reasoning, it appears that the presence of economic interdependence only, is not enough to bring peace. For instance, by mid-18th century, or about half a century prior to the Great War, Europe had experienced a dramatic increase in the level of interdependence 
especially among several of the major powers (2011). On the other hand, Anastasiou argues that "In the context of rampant nationalism, economic interdependency was one of the major factors that brought the nation states of the pre1945 Europe into war" (2007, p. 3). This was obvious because of the nature of the alliances they set up as part of power balances. This became a factor in the early conflicts. Economic interdependency existed at the time but that did not prevent conflict between nation states.

Considering the above arguments, with reference to hypothesis number one, it could also be argued that economic interdependence by itself could not, and does not establish enduring peace. With relevance to integration, a clear explanation is that WWI started among the economically backward, non-interdependent states of Eastern Europe. As such, interdependence appears to have succeeded in averting war where nations were integrated, but was incapable of forestalling conflict where economic integration had yet to occur (Gartzke \& Lupu, 2011). For instance, the type of interdependence that was in operation during the 20th century, and the period before WWI and after, to the period leading to WWII was not a broad-based or global interdependence with free trade in the real sense of it. For example, Germany was largely excluded from the growing economic interdependence of the 19th and 20th centuries. Consequently, increasing pessimistic German expectations had much to do with the German willingness to bring a major war in July 1914. It began with Britain shutting Germany out of the oil-rich Middle East and resources rich Africa, with France threatening Germany's access to iron ore, and with high French and Russian tariff levels, that limited economic growth versus access to economic empires like Britain and the United States (Copeland, 1996). Copeland also emphasize that, when pushed to the brink, German leaders felt that only a 
major war would provide the economic dominance of Europe needed for long term German survival (1996).

Thus, the type of trade relations that was biased, threatening with obstructions and sudden introduction of export quotas, did not portray a proper interdependence. For example, the Anglo-German naval arms race reflected fears on each side that the other might blockade imports to the adversary into submission (Offer, 1989).

In order to further analyze this hypothesis and arrive at a reliable conclusion, two relevant contexts were examined: (i) the relationship between economic interdependence, peace, and prosperity; and (ii) the relationship between interdependence and conflict.

\section{The Relationship between Economic Interdependence, Peace and Prosperity}

In order to unpack the relationship between the above three concepts, it is relevant to repeat Gladstone's question: Does economic interdependence bring peace? (Gladstone, 2007). A good response to this question, would entail assessing the relationship between war and interdependence, from the perspective of traditionalists approach, "capitalist peace or commercial peace" approach, and liberal theories of interdependence. The traditional realist's approach explains how economic ties linking nations change the incentives of actors in the international system (Gartzke \& Lupu, 2011). Advocates of this approach include scholars such as Angell, 1933; Keohane \& Nye, 1977). These scholars argue that interdependence, primarily in the form of interstate trade, raises the opportunity cost of war, thus making contests less likely (Gartzke \& Lupu, 2011). The traditional approach argues that economic ties that link nations appear to change the interests or incentives of actors in the international system 
(2011). These scholars argue that states are better able to achieve gains more efficiently through economic means as trade increases, rather than through warfare (Gartzke \& Lupu, 2011; Rosecrance, 1986). The "Commercial Peace" or the "Capitalist Peace" approach maintains that increase in interdependence reduces the domestic incentive of leaders to engage in wars (Gartzke \& Lupu).

In summary, considering the views expressed by the above scholars and different schools of thought, it could be inferred that, interdependence involves trade, development, open financial markets, and monetary policy coordination. If these factors, are available, and are successfully managed by corresponding institutions, conflict may be reduced by: (1) aligning states interest, which gives them less to fight over; (2) providing a means of peacefully securing resources; and (3) allowing states to see the cost of fighting, which facilitates bargaining and compromise (Gartzke \& Lupu, 2011).

\section{Interdependence and Conflict}

From the perspective of the traditional realist thought, economic interdependence has no significant effect on international conflict (Morganthan, 1964; Rispman \& Blanchard, 1996). Scholars from this school of thought argue that neither the benefits nor the cost of economic interdependence are sufficient to change foreign policy decisionsmaking regarding security issues (Jungblut, 1999). However, liberal trade theory, believes that wars are inhibited by the exchange of wealth across international borders (Gartzke \& Lupu, 2011). In another study, Jungblut, (2011) examines economic interdependence and inter-state conflicts. He based his analysis on versions of the liberal hypothesis, and functionalists' research such as that by Haas and Mitrany (1964), political and economic liberalism (Russett, O'neal, \& Davis, 1998), and theories of 
international exchange (Polachec \& McDonald, 1992). These scholars positively emphasize the advantages of economic interdependence. Other liberal scholars such as Masefield and Pollin, 2003; McDonald \& Sweeny (2007) maintain a similar opinion. On the other hand, critics of the liberal trade theory argue that if economic interdependence had failed to stop or deescalate the conflict that led to WWI, then it might not be a reliable tool or policy to encourage inter-states peace (Buzan, 1984; Copeland, 1996; Papayoanou, 1996). A group of scholars, who maintains the Marxist's point of view, oppose the liberal, functionalist, and realist theories and argue that, interdependence and conflict are unrelated. They also argue that there is no relationship between trade levels and conflict (Ward, 2007). Additionally, they suggest trade increases rather than decrease the likelihood of conflict. As such, this argument is further buttressed by the belief that capitalism leads to conflict (Barbieri, 1996; Barbieri \& Schenider, 1999; Gartzke \& Li, 2003).

Since economic integration failed to bring peace in Europe between1914-18, scholars were skeptical that economic integration and or interdependence are reliable tools in preventing such conflicts in the future (Levy, 2001; Papayoanou, 1999; Ripsman \& Blanchard, 1996; Rowe, 2005). With reference to liberal trade theory, Gartzke and Lupu affirms that WWI was not a complete failure, nor did interdependence fail during the first half of the 19th century (2011). It makes sense to argue that, although WWI occurred, however, the states that initiated the war were not interdependent. However, interdependent states in most cases, participated in the war with a lukewarm attitude but, with a focus to accomplish their economic and political goals. 
Basically, WWI started among the economically backward, non-interdependent states of Eastern Europe (Gartzke \& Lupu, 2011). Therefore, it is pertinent to dismiss the views held by critics of liberal theory that, though interdependent 'powers' went to war in 1914, it does not mean that economic interdependence could not stem the tide of conflict (2011). A fair assessment of the conflict would attribute failure of interdependence to deescalate the Great War on the following factors: (1) the system of European alliances during that period; and (2) the incentives of leaders to limit their options during crisis situations, and the decisions of individual leaders to honor their alliance commitments (2011).

For example, though France and Germany were bitter rivals for decades, the two European powers experienced a long period of peace that spans forty years after the Treaty of Frankfurt (1871); (Gartzke \& Lupu, 2011). These two European states were able to maintain sustained peace because they (France and Germany) were strongly, and economically dependent on each other. Again, interdependence might not have been the only factor for the long period of peace between France and Germany, but it was a strong factor in reducing the incentives for war between them.

Economic integration did not take place in the EU purely because of economic interdependence. In view of the ensuing analysis it is pertinent, therefore, to conclude that while economic interdependence may reduce the incentives for war, however, these factors alone cannot bring peace. Therefore, this hypothesis is partially true.

\section{Hypothesis 2: Expansion of the Free Market leads to Peace}

Free and fair competition involves clearly established rules or leveling of the playing field for all parties involved. A key factor is also the ability to enforce the rules 
effectively as it is done in the EU. Unfair competition was one of the barriers to free trade in Europe beginning from the early 19th century. Other barriers include protectionist agreements, national aids and discrimination in favor of public undertakings-all these are incompatible with the single market policy (Moussis, 2011). Similarly, economic nationalism has been one of the major barriers to free trade and fair competition in European commerce in the 19th century. In the 21st century, however, free markets and economic development have contributed immensely to reduction in interstate conflict (Gartzke \& Hewitt, 2010). A number of benefits that countries derive from free trade are not merely economic. For example, free trade also encourages people and nations to live in peace with one another. Free trade raises the cost of war by making nations more economically interdependent. Free trade makes it more profitable for people of one nation to produce goods and services for people of another nation than to conquer them. By promoting communication across borders, trade increases understanding and reduces suspicion toward people in other countries (Griswold, 1998). Historically, the period 1815-1913 may be described as the century of relative global peace (Griswold, 1998). Accordingly, this period was marked by a remarkable expansion of interdependence - international trade investment and human migration with Great Britain leading in inventions and trade in the century. This dramatic example in world trade and interdependence was disrupted by WWI (1914-1918) and later on, the collapse of the stock market in 1929, followed by the Great Depression and biting hardships of the 1930s. The Great Depression actually brought about disparities in economic factors, such as protectionism, and this resulted in conflicts. As already stated above (in chapter 2), many countries resorted to trade protection and this, coupled with the extreme 
hardship further drove the global trade in the first quarter of the 1920s to the extreme. The rise of protectionism and the downward spiral of global trade in the 1930s aggravated the underlying hostilities that propelled Germany and France to make war on their neighbors (1998).

The mere fact that unforeseen circumstances, hardships, and protectionism had disrupted free trade in the 20th century and resulted in a disastrous global conflict clearly reflects on the relationship between free trade and peace. More so, free trade and global markets are often cited as providing many advantages in both industrialized and developing countries. In an attempt to prove the hypothesis that: expansion of the free market leads to peace, a number of examples will be cited to buttress this claim. Free trade is also a strong promoter of democracy. A clear example in the 21 st century is the fact that free trade has drawn China into the World Trade Organization (WTO) (Griswold, 1998; De Lucas \& Buell, 2006). Global peace has been immensely attributed to free market and a number of concrete examples appear to confirm this fact. First, more than half a century since the end of WWI, no wars have been fought between nations that were strongly involved in bilateral trade policies (Griswold, 1998). Similarly, Griswold explains further that in every one of the two dozen or so wars fought since 1945, at least, one side was dominated by a nation or nations that did not pursue a policy of free trade (1998). Second, in the Middle East, the Arab-Israeli wars/conflicts have been going on since early 1947 till presently. Apparently none of the direct participants were what could be described as open economies at the time of conflict, with Arab countries enforcing boycott of trade with Israel (1998). 
Contrary to the stated hypothesis that expansion of the free market leads to peace, it is noteworthy to mention that, conflicts have broken into a full scale war between India and Pakistan (1965-71), whereas both countries were signatories to the General Agreement on Tariffs and Trade (GATT) when they fought the war; they were also involved in protectionism as a trade policy (Griswold, 1998). Similarly, Great Britain and Argentina were also members of the GATT and both countries were locked in a fierce battle over the Falkland Islands, "the Falkland Wars" in 1982. Paradoxically, Argentina, the aggressor in that conflict, was at the time still under the protectionist spell of Peronism (1998).

With the exception of the few negative examples cited above, there is overwhelming evidence that global peace has been one of the advantages derived from the expansion of the free market or closer economic integration as seen in the EU. As parochial walls between peoples are undermined, interdependence grows and is made more transparent and mutual propensity assured (De Lucas \& Buella, 2006).

From the above analysis, it is obvious that even countries that were signatories to free market organizations went to war with one another. However, to a large extent, there have been a lot of beneficial influences of the free market as seen in the EU. Generally, free market does not, and is not a panacea for peace. Other human factors like politics in form of power and control, greed, racism, the urge to satisfy a nation's dire needs leading to invasion and control of other nations resources like oil, gas, water ways, fishing grounds, and fertile lands often play a role. These are some of the issues that could surpass the advantages of the peace often brought about by the expansion of the free 
market. By and large, the expansion of the free market and economic interdependence does not necessarily secure peace. As such, hypothesis number two is also partially true.

\section{Hypothesis 3: Democratically and Jointly managed Economic Integration will lead} to Sustainable Peace and Economic Prosperity.

In order to ensure that EU citizens and businesses fully benefit from the single

market, the Eurobarometer survey was launched in 2010 by the European Commission

(Eurobarometer, 2006, p. 3). The survey involved 24, 750 European citizens from 25

member states; interviewed face-to-face. Responses from this survey revealed a

positive attitude of EU citizens towards increased competition within the single market.

The European Commission report indicates that, a considerable majority of EU

citizens, sixty seven percent perceives that opening a common market for competition

is a good thing, and a minority of thirteen percent feels that competition is bad

(Eurobarometer). Also, between seven to ten percent thinks that increase competition is

neither good nor bad for the single market.

From the Eurobarometer survey (EC, 2006), it is clear that EU citizens are quite satisfied with the benefits that the single market offers. They are also quite aware of the positive effects of the single market on competition, products and services (EC, 2006). The majority of citizens, (84\%) would like to study in other EU member countries; while as much as seventy percent would like to move to other EU member countries and work there (EC, 2006, p. 6-9). As many as sixty-seven percent of the respondents felt that increased competition is a good thing (p. 12). On the whole, increase in movement of people, products and services have been perceived as having a positive impact on the EU economy and the employment situation in the future (EC, 2006, p. 39). It is clearly observed that citizens of the ten new member countries appear to have more positive 
attitudes towards the single market than their fellow citizens in the old member countries- the EU 15 (EC, 2006, p. 84). This may be partly because they are 'new' in the EU. They are excited about the new possibilities and opportunities that the single market and the EU in general have provided them. The older EU 15 members have already enjoyed, and were used to the possibilities, as such, for them, they are not new and they are more critical (Eurobarometer).

Traveling conditions in the EU are easier today than before the single market. Moreover, with the Euro as a common currency, possibilities in economic transactions have been enhanced (EC, 2006, p.29). However, respondents indicated some inconsistencies in the prices of some products (EC, 2006, p.37) but this does not pose problem or barrier to other benefits they have enjoyed. Access to healthcare and the recognition of academic and professional qualifications across the EU are some other benefits of the single market (Eurobarometer Survey, 2006; EC, 2006, p. 78).

Studies on EU mergers and acquisition provide strong evidence of the impact on the SM program. These studies reveal that intra-European activity increased from 9.95 percent between 1985 and 1993 (Allen, Gasiorek, \& Smith, 1998; EC, 1996). In the area of manufacturing, the share of total sales by the four largest European firms increased from 20.8 percent to 22.8 percent between 1987 and 1993. Reports gathered from studies since 1980, reveals that there has been a steady trend towards greater import penetration with home shares declining and both EU and rest of the world (ROW) shares rising (Allen et al, 1998). The Economist, also reports that an initiative by the European Community (EC) to merge firms that were too small to compete in the global market paid off successfully (1992). 
Increase merger and acquisition activities partly, might be attributed to the remarkable increase in the number of EC firms in the list of the world's top one hundred companies ranked by turn-over. In the same period, the number of firms has increased from thirty-one in 1983 to thirty-seven in 1989 (The Economist, 1992). During the same period, the number of Japanese firms rose from 9 to17, while the American firms fell from 46 to 35 (The Economist). By 1990, the EC had a comparative advantage as its exports to Third World countries amounted to one-fifth of total world exports, compared with fifteen percent for the US, and just nine percent for Japan. During the same period, the EU earned \$535bn from its overall exports, compared to \$393bn for the US, and $\$ 287 \mathrm{bn}$ for Japan. There is no doubt that such an astonishing performance could be attributed to the fact that the EU top manufacturers such as Germany, Britain and France maintain the strong industrial base of the EU. Also, Britain and Holland are in the EU and have been involved in international trade for centuries.

Cooperation has provided a big boost to the EU in that it derives a lot of advantage from EFTA countries which are important trading blocks. European Free Trade Association (EFTA) members like Switzerland and Sweden, apparently, have very small domestic markets but are large exporters of world class cars and trucks such as Volvo, and consumer goods makers like Electrolux (The Economist, 1992). In addition, Switzerland is famous for pharmaceuticals and is home to companies like Ciba Geigy and Sandoz which are world class companies (The Economist, 1992). Swedish Asea Brown Boven is one of Europe's famous engineering industries in the EFTA group (The Economist, 1992; Leonard, 2010; Rifkin, 2004). 
With a slow, but steady advancement in economic and trade progress, the EU has become an emerging economic power, the largest internal market, and the largest trader of goods and services in the world with almost 750 million citizens, compared to about 300 million in the US and 120 million in Japan (Rifkin, 2005, EC, 2002). In the year 2000, EU trade deals amounted to 590.8 billion Euros, or twenty-four percent of the total world trade and services. The US ranked second with 550.9 billion Euros and a twentytwo percent share capital. Japan comes third with 201.6 billion Euros with eight percent share of the global trade (Patten, 2001).

In the area of peace and prosperity, the EU has demonstrated that social progress and personal happiness are only possible under peaceful conditions. Peaceful conditions are enhanced by security. There appears to be a redefinition and reframing of the concept of security in the EU. For instance, well-being in Europe has become a security issue. The institutions of the EU are the building blocks for security. Antithetically, the military may appear as a basic symbol for security, but military power cannot solve all human problems. The SM program has strongly increased welfare for all EU economies, although this welfare provision has not been equally distributed across the EU economies (EC, 2006). It appears that the larger welfare gains are experienced by the smaller economies and this occurs because of greater pro-competitive impact of the reduction in barriers (Allen et al, 1998). Furthermore, the larger welfare gains must have occurred as a result of restructuring, and as welfare gains increase, there is a high degree of integration. From the preceding analyses in hypotheses (1) economic interdependence is the way to establish enduring peace and prosperity, and hypothesis (2) the expansion of the free market leads to peace, it is obvious that economic interdependence, expansion of 
the free market, and economic integration combined together may help to provide peace and prosperity but are not sufficient. What is often missed by analysts of economic integration is that, stability and peace is possible in the EU because economic integration was accompanied by a measure of political integration as well as by building democratic and decision-making institutions at the intergovernmental and transnational levels (Anastasiou, 2007). Again, from the analyses, it is partially true that hypothesis 1 , and hypothesis 2 , would lead to peace but not without the necessary institutions to support and sustain economic integration and peace enhancing activities and programs. Finally, it may be concluded that the relationship between economic integration, peace and prosperity is not straight forward but ambiguous. Therefore, further analysis is necessary in the area of political and economic institutions to see if that can illuminate the relationship further. 


\section{CHAPTER 4: The Political Dimensions of EU Integration}

The EU political and economic institutions, it activities and impact on integration will be the major themes under political dimensions. These factors will shed more light on the importance of institutions in bringing about sustainable peace.

\section{The European Union}

It is hard to answer the question - what is the European Union? The hard part lies in the fact that there has never been an organization, or governing institution like the European Union, with which one may make a comparison. Leonard (2005), for want of comparison, likened the EU to the Visa credit card company which operates in almost one hundred and fifty countries as a financial network. Like Visa, the EU is a decentralized network that is owned by its member states (Leonard). Because it is a network rather than a state, "negotiation is not a part-time activity: it goes on every single day around the clock." (Leonard, p. 24). Although the EU is a network, of

member states, "it is the national government that sets the agenda for the future of Europe" (p. 24). Craig, Cramme, and Craig (2006) attempt to define the EU as an economic and political union of twenty-seven member states, located primarily in Europe (Craig, et al, 2006). Established by the Treaty of Maastricht in November 1993, upon the foundations of the pre-existing European Economic Community, it has a population of almost 700 million citizens, and generates approximately thirty percent share of the nominal gross world products (GWP) (Craig et al, 2006).

Europe's political leaders have been struggling to define the limits of power of the European Community even at the inaugural stage of a united Europe. Among these leaders, two groups were prominent. The federalists-who support a system of 
government with two levels, national and local, with (shared) or separate powers and functions. There is also a direct relationship between citizens and each level of government in the federalist's proposal (McCormick, 2005). The federalists also wanted the ceding of more powers to the Community. On the other hand, the confederalists (those who believed in the system of governance with a higher authority without exercising power over individuals) proposed the type of governance that retains power in the hands of member states (McCormick, 2005). But when the European Community became the European Union, Europeans thought of the EU more as an intergovernmental forum whereby national objectives should be coordinated and each member states' interests remained strengthened (Rifkin, 2004).

From the confederalist's perspective, Lionel Jospin, a former French Minister, and core confedralist states: "I want Europe, but I remain attached to my nation. Making Europe without unmaking France or any other European nation, that is my political choice" (Jospin, 2001, p.1). From Jospin's perspective, the union should be a "Europe of States" (Rifkin, 2004). The EU is a network motivating system;

...its primary role is to facilitate the coming together of network of engagement that include nation states but also extend outward to transition organizations, and inward to municipal and regional governments, as well as civil society organizations (Rifkin, 2004, p. 215).

Rumford (2002) used Michel Foucault's point of view in describing the EU. He states “...every level of governance is embedded with every other level in a continuous process of engagement - (reflects a new way of thinking that facilitates feedback and inclusion of all the potential actors)" (p. 71). Foucault referred to this process as "governmentality" (as quoted by Rumford, 2002, p. 72). In his explanation of a 'continuous process of 
engagement', Dean, a sociologist, defines "governmentality" as "the relationship between the government of ourselves, the government of the others, and the government of state" $(1999$, p. 2). In relating this concept to the EU, government of the state becomes only one player among many diverse players in the political game (Rifkin). For example, in this system, the state is no longer sovereign. It loses its power as the exclusive agent responsible for disciplining its citizenry. The exercise of power becomes much diffused and decentralized. According to Dean, this kind of governance may be referred to as "government without a center, a form of administration in which there is no longer a centrally directing intelligence" (p. 2).

In terms of its structure, the EU is not a state, even though it acts like a super state. It has laws that supersede the laws of all the member states combined. It has a single currency, the Euro, which is used by many of its member states. It regulates commerce and trade, coordinates energy, transportation, communications and education in all the countries that make up the Union (Rifkin, 2004). Its citizens are free to carry a common EU passport, as European citizens. The EU has a parliament which makes laws and a European Court that makes decisions which are binding to member countries and the citizens of the EU. It has a president, and a standard military force. The EU has all aspects and rights of a state, but two salient limitations are, it cannot tax its citizens, and member states have the prerogative to veto any decisions that might commit their troops to be deployed during external conflict. Another prominent characteristic is that the EU has no geographical boundaries because it is not a territory (Rifkin). However, it coordinates and regulates activities that enhance its policies within the territorial boundaries of its member states. The EU "has no claim to territory, and is... an extra- 
territorial governing institution" (Rifkin, p. 198). This lack of defined territory is an element that portrays the EU as a unique institution because territory inspires a concept of nationalism. Nationalists and nation-states maintain geographically defined institutions that lay claim and control to specific territory (Anastasiou, 2008b; Rifkin, 2004).

The EU is not bound by territorial constraints (Rifkin, 2004) and its enlargement power is unpredictable. Its criteria for membership are value based rather than geographically determined. Rifkin also argues that, "If it is hard to grasp what the EU is, it is because it is continuously metamorphosing into new forms as it adjusts to fast moving new realities.” (p.199).

\section{European Union Economic Policies}

In the context of joint decision making that EU institutions made possible, the EU developed numerous policies and instruments, thereby, fostering economic integration. Since its inception, economic policy has been the dominant feature of the EU. These policies have been established by its various treaties and ratified by member states. Starting with the Treaty of Rome in 1951, the six founding members of the European community were Belgium, France, Italy, the Netherlands, Luxembourg, and West Germany. They agreed on the pooling of coal and steel industries together, and moved on to the creation of a common market in 1957. From that time onwards, the EU has gradually spread into a plethora of economic, social, and political activities. The treaty of Rome also established a customs union that removed all tariffs, barriers and other obstacles to trade among its members. It created a common external tariff, and a common commercial policy towards their countries (McCormick, 2005). The European 
single market allowed free movement of people, money, services and goods throughout EU member states. The Common Agricultural Policy (CAP) was also created to provide farmers with a guaranteed price for their produce, stabilize the market, and assure continued food supply (Holden, 2003; Leonard 2010; McCormick, 2005; Surranovic, 1998).

The Brussels Summit (of the European Council) of 1985 was convened to review and complete the dream of a single market with no barriers to trade, freedom of access and movement of people, money, goods, and services. With these goals, legal residents of the EU would have the right to live and work in other member countries. Their professional licenses would also be recognized. Money-currency and capital would be allowed to flow freely across borders of EU member states. The SM policy also involves free movement of goods and services. People could sell their products in any member countries throughout the EU (Lairson \& Skidmore, 1997; McCormick, 2005). Additionally, the Single European Act (SEA) of (1986) was created to remove barriers in the physical, fiscal, and technical areas of the European economy. Over the years, a monetary union was suggested by the members of the EEC. This important goal was finally formed in January 1999 when eleven member countries (or the Euroland) supported and introduced a single currency-the Euro. The Euro is the legal currency of the EU. In 2002, Euro notes and coins that were already legal tender in 1999 replaced all other currencies and coins of eleven member states. Now, twenty eight member states of the EU share a single monetary policy and a single foreign exchange rate policy. The benefits of the Euro include reduction of transaction costs, the elimination of exchange rate risks, increased price transparency, and the creation of deep financial markets. 


\section{Major Treaties that Established the EU Institutions}

Among other things, democracy is a system of powerful institutions with norms and constraints that help to prevent conflict and encourage peace. As such, institutions pose an analogous barrier to violence (Gartzke \& Hewitt, 2010). One such norm or constrain within the EU is the common fact that democracies do not go to war with each other because force is not a sanctioned method of competition within the democratic political process (2010). The EU Copenhagen criteria (1993) emphasize that, any country that wishes to become a member of the union must have (i) a functional democracy, observe human rights and the rule of law; (ii) a functional market economy and the capacity to cope with a competitive pressures of capitalism; and (iii) the ability to practice the obligations of the Acquis Communitaire (the established body of laws and policies already adopted by the EU (EC, 1993; McCormick, 2005). These factors are some of the greatest reframing that the EU has achieved in maintaining peace. For instance, the EU appears to see warfare as a regression from democracy. That is, "you cannot be pro-war and pro-democracy at the same time" (Anastasiou, 2008b).

The Treaty of Paris (1951) that established the ECSC was signed by France, Germany, Italy, the Netherlands, Luxemburg, and the Benelux countries. These six member countries that signed the treaty of Paris and established the ECSC also came in one accord and signed the treaties establishing the European Economic Community (ECC), and the European Atomic Energy Community (EURATOM). As such, these two treaties (EEC, and EURATOM) are often referred to as the 'Treaties of Rome" (1957) (Nelsen and Stubb, 2003). This treaty, served to provide the ultimate and larger part of 
the authority for the decisions and responsibilities of the European Community-the foundation of European integration (Leonard, 2010).

A closer look at the initial treaties would reveal that they were designed to secure peace and economic progress in Europe. Additionally, the preambles to each of the three original treaties reflect the founders' vision and explain the general goals and principles through economic integration and the specific tasks that would be undertaken by EU institutions (McCormick, 2005; Nelsen \& Stubb, 2003). Specifically, the preambles clearly define the deep desire for peace on the European continent and link them to the visions articulated by the founders: Spinelli and Rossi, Churchill, Schuman, Monnet, and other European leaders. In laying much emphasis on peace, it is not surprising to note that the treaties also present an emphasis on economic prosperity as a driving force for unity (Nelsen \& Stubb, 2003). This is a strong indication that the founders of the EU believed economic integration and institution building had to work hand-in-hand to achieve a sustainable peace.

The Treaty on European Union-also known as the Maastricht Treaty-was concluded in 1991 and signed in 1992. It was a complete revision of the Treaty of Rome comprising two major sets of provisions: the establishment of an economic and monetary Union (EMU) by 1999; and those described as steps towards political union, comprising common foreign and defense policies (Leonard, 2010). A few other provisions extended or defined more clearly the EC's role in other policy areas and amended the powers of various EC institutions. The Maastricht Treaty also established three fundamental strongholds for the EU: (i) it combined the three existing EC treaties (the ECSC, EC and EURATOM); (ii) it established a new provision on a common foreign and security 
policy (CSFP); (iii) it made provision that fosters cooperation in justice and home affairs (2010).

The Treaty of Amsterdam-signed in 1997, became effective after ratification in 1999. It was basically, an arrangement that improved the Common Foreign and Security Policy, brought the Protocol on the Social Policy and the Schengen Agreement into the EC framework. It also extended the powers of the European Parliament and the president of the Commission, added Employment and 'Flexibility' clauses, and enhanced greater transparency (Leonard, 2010). The Treaty of Niece (2001) is solely concerned with revising the membership and voting power of EU institutions as enlargement continues to expand, and the number of member states that joined the EU increased during the first decade of the twenty first century (Leonard, 2010).

The Treaty of Brussels (2004) or the treaty that intended to revise a draft constitution for Europe concluded in Brussels in June 18, 2004, and was signed in Rome on October 2004 (Leonard, 2010). This treaty brings all other treaties into a single document. It defined which decisions would be taken by the EU, which would be reserved exclusively for member states, and those that should be shared. However, this treaty was abandoned and the EU did not manage to establish a first transitional constitution.

A second attempt was made with the Treaty of Lisbon (2007), ratified and signed in 2009. The Lisbon Treaty comprises a long series of amendments to the Treaty of Rome and other EU treaties (Leonard, 2010). These treaties contain broad and ambiguous goals, and set the foundations for policy that would be turned into specific actions in the form of new laws for the EU (McCormick, 2005). 


\section{EU Institutions and Shared Sovereignty}

One may ask why such a number of treaties were necessary before peace could be attained. The array or series of treaties that paved the way for European integration went beyond the classical concept of piecemeal inter-state agreements, pacts, and trade arrangements. What makes the European treaties of the late twentieth century unique is that, in facilitating European integration, they entail among other things, the establishment and strengthening of supranational and inter- governmental institutions (Anastasiou, 2007). The latter, made possible perpetual and joint democratic management of relationships between European states, and between their respective societies at numerous economic, social and political levels (Anastasiou, 2007). To further strengthen the process of joint democratic management, the EU has developed a system of governance which exhibits a unique division of responsibilities between its institutions and member states, based on the principle of "subsidiarity" (Cramme, 2011). The principle of subsidiarity refers to the process whereby decisions should be taken at the lowest level possible, for effective action (McCormick, 2005). It is a popular notion that all government policy should be enacted at the smallest or most immediate level of government, that is, at the local rather than regional, regional rather than national, and national rather than at the EU level (Hill, 2010).

A simple explanation of the concept of sovereignty is the right for a state to hold and exercise supreme power. It also means independence, being free from external authority or influence (Funk \& Wagnall, 1971). In the context of the EU, "shared sovereignty" or "pooled sovereignty" in practice is the process whereby, member states delegate some of their decision-making powers to shared institutions they have created, so that decisions 
on specific matters of joint interest can be made democratically at the European level (Anastasiou, 2007; EU Institutions and Other Bodies, 2006).

From its formative stage as the EC, the EU has gradually expanded its regulatory authority, evolving from a customs union and free-trade area, to the Single Market and a common currency. Obviously, the pooling of sovereignty appears to be the strongest and most crucial activity in the case of the European Monetary Union (Cramme, 2011). It is crucial because monetary policy and exchange-rate instruments of macro-economic management have now been vested under the control of the European Central Bank; fiscal policy is subject to strict supervision within the framework of the Stability and Growth Pact. Furthermore, supply side reforms are closely monitored, if not coordinated, through programs seeking to foster greater economic convergence (Cramme).

The EU institutions have been designed and structured to make Europe one of the most peaceful and evolving regions of the world. The EU is a unique case of an institutionalized peace-building system. The idea of the system, in practice, expels the fear of lethal encounters among European nations. Historically, conflict has been part of the European experience since 1914, but the EU process is the most spectacular effort in conflict transformation in the world (Anastasiou, 2008b).

The effective management of relationship through institutionalized decision-making is done more effectively by sharing, or by joint management, and this ensures peace and accountability (Picht, 1975). Economic interdependence could be a strong and reliable tool in preventing wars and conflicts as in the EU when it is combined with institutionalized multilateral cooperation among member states (Anastasiou, 2007). From the point of view of the EU, a remarkable amount of success in attaining sustainable 
peace should be attributed to the political institutions and not only economic interdependence. Integration is the powerful tool or policy that makes it easy for pooled sovereignty, and intergovernmental management of merging economies, and democratic governance. EU member states have more to benefit from pooling their sovereignty together especially in the area of economic development. The surrendering of more political national sovereignties to a broader political union provides long term solutions that strengthen the union. In return, member states gain a greater measure of security and opportunity (Rifkin, 2004).

The EU has emerged as the first mega governing institution. Its mission includes to lay the foundations for an ever closer union among the peoples of Europe. A closer look at the preamble to the Treaty of Rome (1957) which established the European Community states:

...to substitute for age old rivalries the merging of essential interests; to create peace by establishing an economic community, the basis of broader and deeper community among peoples who were long divided by bloody conflicts; and to lay the foundations for institutions which will give directions to a destiny hence forward shared (www.europa.eu.int).

By working through agreements and cooperation with member states and others, the EU has earned the attribute as the "first political entity in history whose very reason for existence was to build peace" (Shore, 2000, p. 15).

North (1981) defines institutions as "a set of rules, compliance procedures, and moral and ethical behavioral norms designed to constrain the behavior of individuals in the interests of maximizing the wealth or utility of principals" (1981, p.201-202). Commenting on North's definition, Glaeser, La Porta, Lopez-De-Silanes, and Shileifer (2004) argue that, the word 'constraint' appears to be a key word that differentiates 
North's definition from others. As such, “constitutions or electoral rules are good examples of institutions, but good policies chosen by dictators who have a free hand are not" (p. 275).

EU institutions are established by treaties, the ultimate authority for decision making, power to act, and provide responsibilities for its various functionaries (Leonard, 2010). Numerous treaties conducted towards European integration went beyond normal interstate agreements, economic cooperation, pacts, and trade arrangements. The treatises are outstanding in the context of European integration because they initiated "institutionalizing at the supra-national and inter-governmental levels..." (Anastasiou, 2007, p.37). In order to become an authentic integrative model, the EU created an institutionalized system of "democratic management" of transitional interests which could no longer be managed unilaterally by individual states (Anastasiou, 2007). Outstanding among the treaties were the Treaty of Paris (1951) which established the European Coal and Steel Community (ECSC); and the Treaty of Rome (1957) which established the European Community; and more significantly, the Treaty of the European Union in 1992. Again, Anastasiou has stated that, "The structure and logic of EU institutions are indicative of the unique manner in which the European experiment historically amplified, deepened and expanded democracy in direct association with conflict prevention and peace building...” (2007, p. 37).

The EU operates through a hybrid system of inter-governmentalism and supranationalism (Leonard, 2005, Rifkin, 2004). It also has supranational bodies that are able to make decisions without unanimity between all national governments. Important EU institutions and bodies include: the European Commission, the European 
Parliament, the Council of Ministers, the European Court of Justice, and the European Central Bank, to mention a few.

The European Commission (EC) is the executive arm of the EU, it initiates policies and implements existing ones. The Commission is mandated with the task of preparing and recommending bills for enactment into EU law, which is passed to the European Parliament and to the Council of the EU for final decision. Because the power of the EC supersedes the national interests of individual member states, it incorporates and integrates diverse interests of member states by focusing on the "common good" of the EU as a whole (Anastasiou, 2007). By so doing, the democratic process is firmly institutionalized and conducted in the transnational dimension of politics. The Council of Ministers (CM) currently consists of twenty eight members, one from each member state. In the Council of the EU, each Minister participates as the representative spokesperson of the national concerns and priorities of his or her country. At the Council level, the democratic process thus assumes an inter-governmental structure.

A very significant aspect of EU integration manifests in the multilingual/multicultural European Parliament (EP). In the parliament, "each party brings together Germans, French, Dutch, Greeks, Italians, etc., elaborating citizen-based party politics across societies, ethnicities, cultures and languages, and, most importantly, across nation-states" (Anastasiou, 2007, p. 38). The EP largely performs an advisory role, and also co-legislates with the Council of Ministers on the bulk of EU business (Leonard, 2010). The parliament also performs the function of bringing some democratic control and accountability to the other institutions of the European Commission (Leonard, 2010). The power of the EP has been increased at the 1992 Maastricht Treaty 
to include "a reinforcement of the EU's post nationalist, citizen-based system of regional democracy" (Anastasiou, 2007, p.38).

The European Court of Justice (ECJ) is based in Luxembourg, and its main function is to interpret and enforce the law in accordance with the provisions of the European Union, especially in the event of a dispute (Leonard, 2010). The ECJ currently has twenty-eight judges selected by the Council of Ministers from each of the twenty-eight member states, plus eight advocate generals. As one of its role expectations, "the European Court of Justice, in its sphere of competency, raises the rule of law above the limitations of national law, while strengthening the rule of law within each of the member states" (Anastasiou, 2007, p. 38). As in the European Commission, the judges of the European Court are also expected to transcend the national interests of their nation-state (Anastasiou, 2007).

Other important EU institutions are: The European Council, the Economic and Social Committee and the Committee of the Regions, the Court of Auditors, and the European Investment Bank. Considering its structure and functions, EU institutions are designed to impact integration. It is because of how the EU institutions are structured that democracy has expanded, in the interest of conflict prevention and peace building. Furthermore, "European living standards, growth rates, and economic structure would have been little different in the absence of the institutions and processes that have culminated in today's European Union" (Eichengreen \& Boltho, 2008, p.1). The conclusion to hypothesis number three is that, economic integration would lead to sustainable peace and prosperity when combined with relevant institutions democratically and prudently managed. 


\section{CHAPTER 5: The EU Network Commerce: A Model of Integration}

In this chapter, network process gives us an understanding of how interdependence functions effectively among EU member states. 'Network' simply means communicating, sharing of ideas, vital information regarding services, products, environmental conditions and their impacts on businesses and services. Again, in the EU, network process is enhanced by the regulatory activities of the various institutions such as the European Commission and the European Court of Justice.

In the current global world, it is common knowledge that feeling autonomous, or going it all alone in business is an indication for failure at some point in time. It is only by pooling resources together and sharing risks and revenue in a network-based relationship that firms can survive (Rifkin, 2004). The concept of a network system, as in the EU, implies giving up some autonomy in exchange for some entrepreneurial advantages and security that come with network arrangement (Rifkin). For example, in a global economy, everyone is connected and becomes interdependent. It becomes quite clear, therefore, that any person who claims autonomy, or is a free agent and hopes to maximize their gains appears old fashioned or completely out of place. As such, a network is the only cooperate model that can generate speed, complexity, and diversity (Rifkin, 2004).

The EU network commerce could be traced to the period when six European states agreed to pool their resources together at the Treaty of Paris (1951) to establish the European Coal and Steel Community (ECSC). Six years later, the network was further strengthened with the formation of the European Community by the Treaty of Rome on 
March 25, 1957. The "network commerce" is different from the "markets" that operated in Europe during the first part of the 20th century. Markets of that era were marked by stiff competition, autonomy, and exchange interactions with purely traditional practice of give and take, between buyers and sellers (Rifkin, 2004). These types of practices have fallen short of the challenges of global network economy of the $21^{\text {st }}$ century. The EU network commerce is unique. It fits into its economic and governing activities of all its institutions, penetrates national borders, and involves all member states. Network commerce enables interdependency and democracy to function effectively in the EU. Rifkin (2004), asserted that the network model and its impacts on institutional changes is driven by the "communication revolution" that impacts the "speed, pace, flow, density and connectivity of commercial and social life" (Rifkin, p. 182). Rifkin further outlines the factors of a successful network as: reciprocity and trust, surrendering of autonomy, and shared vulnerability.

Consequently, network commerce has various advantages such as, sharing of ideas and vital business information that may not be easy to obtain by an autonomous agent or in adversarial circumstances (Rifkin, 2004). Network activities have been a factor behind the remarkable creativities and innovations that many EU industries have so far achieved. Network system has functioned structurally to promote integration and freedom in the EU. For example, the single market has incorporated market activities with network activities and these have made borders between member states less fixed and more porous (Rifkin). Networks are also strongly associated with freedom - the ability to interact far and wide, explore new relationships, and make choices without coercion. 


\section{The Single European Act}

Practically, the provisions of the Single European Act (SEA) of 1987 were a strong move that brought the Member States a step closer to union (Rifkin, 2004). The SEA extended powers to the European parliament and introduced qualified majority voting especially in areas where unanimous votes of member states were previously required. Above all, the SEA established the idea of "Exclusive Community Competent," meaning that, it restricts members states from acting in many areas that had previously been entirely "the prerogative of national governments, including matters related to economic and monetary union, social cohesion, research and technology development as well as environmental policies" (Ruttley, 2001). Moreover, the SEA was packaged as purely a technical treaty designed to further economic and fiscal integration.

\section{The Single Market (SM) and the Single Currency}

In macro-economic terms, the removal of barriers between financial markets in the EU has led to changes ranging from the abolition of exchange controls to initiatives among securities and commodity markets to work more closely together and to compete with American and Japanese rivals (The Economist, 1992). The single market is also characterized by the establishment of a number of cross-border joint ventures and mergers by various financial institutions in the EU area and ensures customer protection (Rifkin, 2004; The Economist). In order to maintain discipline and fair play, regulatory principles have been introduced and these aimed at increasing the level of transparency in financial dealings within the Single Market. A uniform consumer protection scheme has also been introduced to boost the interest of consumers.

Following the Maastricht Treaty of 1992, the European Community was transformed into the European Union; an organization that was far more than a mere economic 
market. One of the three pillars upon which the new EU was to be supported was the introduction of a single EU- wide currency (McCormick, 2005; Rifkin, 2004). Without a doubt, the Euro is the world's second largest currency after the US dollar. The Euro was created in 1997 as a unit of account for the European Union monetary system. The single currency appears to complete a series of developments of the single market. That is, without the single currency, the goal of the single market would not have been realized. For instance, in the United States, businesses in one State can be involved in transactions with business in other states with certainty that a dollar is worth the same everywhere. In the EU, the single currency was introduced with a similar aim. Before the introduction of the Euro, "companies suffered the problem of currency hedging activities and this frequently resulted in big losses" (The Economist, 1992, p.93). Currency fluctuations, therefore, became a significant source of distortions in business transactions. The aim of the single market was to level the playing field for businesses. Since Europe has begun the process of integration from the ECSC, to the European Community, and finally the EU, the continent has experienced a period of significant and sustained peace since 1945 . Europe has also experienced significant development and prosperity that is still ongoing.

\section{What is the Single Market?}

The single market (SM) is one of the outstanding projects of EU economic integration. It is sometimes referred to as the (Internal Market), a befitting description of the EU project to "create a free trade within the EU and to mold Europe into a single economy." (Civitas, 2012). Established by the Treaty of Rome (1957), it has been developing gradually since the formation of the European Community and has fully 
functioned in recent years. The single market is based on four freedoms of movement for goods, services, people and capital, "all within a single regime of competition rules" (EC, 2006, p.3). With relevance to the European Union, the 'single market' implies that there are no barriers to trade. It was known as the 'common market' during the earlier period of the European Community (McCormick, 2005).

The primary aim is to "promote through the community a harmonious development of economic activities, a continuous and balanced expansion, and increase in stability and accelerated raising of the standard of living and closer relations between the States belonging to it." (Moussis, 2011, p.1). In order to ascertain progress toward the realization of this policy goal, the Eurobarometer on the internal market was launched between February and March of 2006. The survey was carried out in twenty-five member states. Approximately 24,750 European citizens were interviewed face to face (EC, 2006). The report examined the extent to which the citizens of EU were familiar with the single market and to what extent they appeared to have benefited from it (EC, 2006).

Traveling conditions in the EU are easier today than before the single market. Moreover, with the Euro as a common currency, possibilities in economic transactions have been enhanced (EC, 2006, p.29). However, respondents indicated some inconsistencies in the prices of some products (EC, 2006, p.37) but this does not pose problem or barrier to other benefits they have enjoyed. Access to healthcare and the recognition of academic and professional qualifications across the EU are some other benefits of the single market (Eurobarometer Survey, 2006; EC, 2006, p. 78). 
Member countries enjoy full benefits of factors of production (land, labor, and capital) that have become more efficiently allocated. The availability of these factors of production has led to a significant increase in productivity (EC. 2006). Both businesses and consumers enjoy a competitive business environment because the (SM) has rendered the existence of monopolies very difficult. Consumers of services and products derive a lot of benefit from the SM in that the "competitive environment has brought them cheaper products, more efficient providers of products and also increase choice of products" (EC, 2006; Rifkin, 2004).

Other important benefit of the EU single market is the fact that it was designed to create economies of scale. That is, EU businesses would continue to increase profits through their production and sales activities without increasing costs. The single market enhances the establishment of commerce among member states, and encourages increase in the growth of commerce by setting and enforcing the same rules across the EU. A good example is the single 'Eurotariff' established by the EU to limit the cost of using a mobile phone within the EU (Civitas, 2012).

The single market is not without its short-comings. Increased international competition deprives local enterprises national protection and national subsidies; consequently, they may struggle to survive against their more efficient peers (EC, 2006). Companies without strong organizing power and with an inability to effect reforms to meet prevailing standard, may fail and this may lead to unemployment and migration. Moreover, the EU cannot be described as a true single market on the following reasons: (i) it does not have a unified taxation or welfare system; (ii) the single currency is not 
used by all member states of the EU; (iii) some member countries have opted out from rules such as the Schengen Agreement (Civitas, 2012).

\section{Contributions of the Single Market to EU Economic Integration and Peace}

The single market and the SEA marked a turning point in European integration

(Wallace \& Wallace, 1996, p.125). One significant aspect of the single market is that it promotes economic integration and leads to prosperity and well-being. The SM enhances trans-border democratic process in the European Union and consequently leads to peace. It eliminates obstacles to free flow of import and export of goods and services among member states. It ensures the acceptance of common agricultural policies, transportation policies, technical standards as well as health and safety regulations (Eurobarometer, 2006). It maintains a common measure for consumer protection. It establishes and maintains common laws to enforce fair competition throughout the EU and to fight monopolies of illegal cartels. It regulates greater monetary and fiscal coordination among member states and certain common fiscal policies (Eurobarometer; www.Scribd.com/doc).

The single market has brought about a significant increase in the movement of people, products, and services across EU member states (Eurobarometer), and these have created a positive impact on the entire EU economy. The single market facilitates traveling, moderate prices of goods and services, boost the production of new variety of commodities, products, and provide access to healthcare and other services (EC, 2006). In a nutshell, from facts and figures from the Eurobarometer, the single market has improved standard of living in all EU member countries (2006). Evidently, given all the contributions of the single market, "what Europe has done is to build into its economic 
system a degree of fairness, consultation, and democracy; that has contributed greatly to ensuring that its prosperity is broadly shared" (Hill, 2010, p. 65). This prosperity has reflected on the EU's economic and social disparities reduction.

\section{Economic and Social Disparities Reduction}

One of the EU's frameworks of solid economic integration was the establishment of the Structural and Cohesion Funds as unique inter - and transitional instruments to guide sustainable socio-economic development across European societies (Anastasiou, 2007). These funds cover one third of the EU's budget and have been reserved specifically for programs such as: the European Regional Development Fund (ERDF) and the European Social Fund (ESF). The ERDF has been designed to take care of programs such as general infrastructure, innovation and investments. Money from the ERDF is available to the poorest regions across the EU (EC. 2006; Leonard, 2010). On the other hand, the ESF funding covers "vocational training projects and other kinds of employment assistance, and job creation programs" (Leonard, p. 170). In terms of ameliorating economic hardships, the program focuses on four major areas:

...increasing adaptability of workers and enterprises, enhancing access to employment and participation in the labor market, reinforcing social inclusion by combating discrimination and facilitating access to the labor market for disadvantaged people; and promoting partnership for reform in the field of employment and inclusion (p. 170).

In designing programs for economic development, the EU at the same time aims at "reducing economic disparities in all its regions by supporting regional growth and conversion, developing infrastructure and telecommunications, developing human resources, supporting research and development, financing and guiding environmentally sound practices conducive to sustainable economic growth" (Anastasiou, 2007, p.4). 
Rifkin describes this social disparities reduction as follows, "The New Europe is knocking down the walls, the borders, the boundaries, the endless demarcations, that have separated people from their neighbors and strangers for more than two millennia of history" (2004, p. 60). Europe has fulfilled the primary goal of integration through reconciliation between France and Germany. The unification of East and West Germany and its efforts in peace-building in between neighbors like Greeks and Turks, Catholics and Protestants in Northern Ireland, as well as extending economic growth to Central and Eastern European countries are some of the examples.

\section{Fair Competition as an Element of Integration}

The fact that the single market program was designed to generate structural changes in the EU is undisputed. The aim was to make it possible for competition on equal terms on the markets of all the member states. The common competition policy is essential to the achievement and maintenance of the single market (Moussis, 2011). Therefore, "in order to make the single market a truly level playing field, the founding Treaty laid down tough legal procedures to ensure that competition is fair" (Euromove, 2011, p.1). Trade barriers were some of the existing structural imperfections in European markets before the EEC, and the EU era. In order to remove trade barriers, and accomplish this great goal, enormous power was invested upon the European Commission as an independent body to check the advances of Member States. The single market policy (SMP) has also been established. In an effort to sweep away physical barriers, the (EC) published a list of 282 measures to abolish the restrictive activities and non-tariff barriers in Europe by the end of 1992 (The Economist, 2010). The EC also set out to replace national norms with European norms by harmonizing standards. The Commission boldly and diligently 
executed its actions to create a true single market by eliminating technical barriers to trade, such as product standards except on some house-hold items (Leonard, 2010) without this approaches, harmonizing would not have been possible.

State aids and subsidies to national firms and industries are equivalent to protectionism. It is an act whereby member states might adopt to protect their domestic businesses by "shielding them with tariff walls" (Euromove, 2011, p.2). It is a factor that is detrimental to fair competition. One of the responsibilities of the Commission is to "prevent government of member states from interfering in the market with state subsidies (or other forms of aids) to companies or to prevent national firms from mergers or take-overs" (Euromove). In order to throw its net on the whole of the single market area and the EEA, "The national competition authorities and the Commission cooperate within a network in order to monitor business agreements and punish infringement of the European competition rules" (Moussis, 2002, p.2).

Illegal activities of monopolies and cartels such as abuse of their dominance are considered barriers to the single market and are prohibited by the Treaty of Rome (Euromove, 2011, p.2). Allen et al, emphasize that "the central purpose of the SMP is to remove regulatory obstacles to competition, allow firms to expand their market without monopolizing them, and enlarge the variety of choice available to consumers" (Allen et al, 1998, p.448). Radaelli (2007) also argues that, "better regulation means a focus on economic competitiveness and a reduction in the administrative burden on industry" (Radaelli, 2007, p.190). The extension of the EU competition rules to the whole European Economic Area (EEA) shows the determination of the EU in enforcing its fair 
competition policy. Therefore, Article 81 and 82 "which ban agreements and abuse of dominant positions respectively, are now applicable in Norway, Iceland and Liechtenstein in Article 53 and 54 of the EEA agreement" (Moussis, 2002). However, less strict rules of competition have been designed in the association and cooperation agreements concluded with the independent states of the former Soviet Union (Moussis). Similarly, the EU has extended its fair competition policy to its largest and long-term partner, the US. According to Moussis, such an agreement is "intended to promote cooperation and coordination between the competition authorities aimed at combating anti-competitive practices with a global dimension" (p.3). Moreover, the same agreement on cooperation and anticompetitive activities on trade and business is in existence between the EU and governments of Canada (Decision 1999/445) and Japan (Decision 2003/520) respectively (Moussis). 


\section{CHAPTER 6: Concluding Observations}

To sum up, the combination of economic integration with a system of institution building and democracy, has contributed significantly to peace and stability in the EU. There were three hypotheses in this study. The first hypothesis (economic interdependence is the way to establish enduring peace and prosperity) asserts that economic interdependence in, and of itself cannot establish enduring peace and prosperity. It must also be coupled with institutions effectively and democratically managed. The second hypothesis (the expansion of the free market leads to peace) asserts that, the expansion of the free market and economic interdependence without democratically managed institutions does not necessarily secure peace. The third hypothesis or the general hypothesis asserts that (democratically and jointly managed economic integration will lead to sustainable peace and economic prosperity). In other words, peace and prosperity can only occur as a result of effective and prudent institutionalized democratic management of economic interdependence of free market and of economic integration. From the analysis, it may be concluded that, while hypothesis 1 and 2 are partly true, hypothesis 3 is true.

Economic integration has contributed to peace in the European Union because of the institutional frameworks set up to enhance sustainable peace. In the context of the EU, institutional frameworks include systems of rules and policies that are essential to maintain law and order, and to establish structures that maintain the integration process. This thesis has successfully addressed the problem statement and research question as stated in the introductory chapter. The transition from war and conflict to peace and 
prosperity reflects a change from the old order to the rise of a new age of the European Union. The decision by European nations to come together to forge unity and cooperation was more than an attempt to correct the wrongs of the past. It was an attempt to formulate a better future for a peaceful and prosperous Europe, with a specific agenda to abolish conflicts among European nations. Economic integration with effective management through relevant institutions have enabled Europe to exist as one whole united entity enjoying a high standard of living when compared with other regions of the world. There is no more "Western Europe" and "Eastern Europe" because common European treaties, a common currency unit, a network of economic activities and many other institutions have been put in place to further strengthen the Union. Finally, from this study, it is obvious that economic integration by itself cannot guarantee peace. It is when economic integration is combined with political institutions, democratically and carefully managed that peace is maintained. Since the 2008 global economic crisis, the economic situation for EU citizens has suffered. Since then, the EU has struggled through it institutions, and new mechanisms, to respond effectively. Time will show if it succeeds to offset the current impact of global recession.

\section{Limitations}

It is believed that as the EU continues to evolve, it will be studied, and more will be learned about this supra-national organization. A few theories of integration and peace mentioned in the study do not appear to have a universal appeal, and are not used quite frequently in the literature or in social science. Data collection is another limitation is this study. Human subjects have not been interviewed on the economic issues in the EU. 
As such, the process of analyzing data with reference to the individuals' or subjects' real life experience is lacking in the study because of the dearth of resources to carry out this task on the ground in the EU. However, the sources of information, data, and analysis presented are reliable, appropriate, and relevant to the study.

\section{Recommendations}

This study is based on a number of variables viz economic integration, transformation, and peace-building. Subsequent study on the topic may deem it appropriate to approach the variables in a systematic way, to show more explicitly the structural relationship between the variables. With more time and resources, data might be collected and analyzed for more reliability. Despite the limitations listed above, I am passionate about the values of the EU, and how these values have been used to effect changes that fit into the global template of the modern world. My interest and commitment in the EU and peace studies is unwavering. Hopefully, this study may be attractive to students and professionals in the arts and social science fields to continue in sharing and expanding knowledge. 


\section{REFERENCES}

Allen, M.G; Gasiorek, M; \& Smith, A. (1998). The competition effect of the Single Market in Europe. Economic policy, 13, 439-486.

Anastasiou, H. (2007). The European Union as a peace-building system: Deconstructing nationalism in the era of globalization. Journal of International Peace Studies. 12, 2.

Anastasiou, H. (2008 a). The Broken olive branch. Nationalism, ethnic conflict, $\&$ the quest for peace in Cyprus. Syracuse, New York, NY: Syracuse University Press.

Anastasiou, H. (2008 b). European Union: Class lecture notes. Conflict resolution graduate program \& international studies. Portland State University. Portland, Oregon, OR. (Spring, 2008).

Angell, N. (1933). The Great illusion, (2nd. ed.). New York, NY. Putnam.

Civitas (2012). EU facts: The European Single Market. Accessed 10, September, 2013 from http://cc.europa/internal+market/index_en.htm

Barash, D.P. \& Webel, C.P. (2002. Peace \& conflict studies. London: Sage Publications.

Barbieri, K. \& Schneider, G. (1999). Globalization and peace: Assessing new directions in the study of trade and conflict. Journal of Peace Research, 4, 387-404.

Barbeiri, K. (2000). The Liberal illusion: Does trade promote peace?: University of Michigan Press.

Bonisch, A. (1981) Elements of the modern concept of peace. Academy of sciences. Journal of peace research, 2, 18.

Buzan, B. (1984). Economic structure and inter-national security: The Limits of the liberal case. International organization, 38, 597-624.

Byrne, A. V; Matic, M; \& Fissuh, E. (2009). Awareness \& process: The role of the European Union Peace II Fund \& the international fund for Ireland in building the peace dividend in Northern Ireland. 
Copeland, D. C. (1996). Economic interdependence and war: A theory of trade expectations. International security, 20, 4.

Craig, P; Gramne, D. B; Craig, P. P. (2000). EU laws: Texts, cases \& materials. Oxford, UK: Oxford University Press.

Copeland, D. C. (1996). Economic interdependence and war: A theory of trade expectations. International security, 20, 4.

Cramme, O. (2011). The power of European integration: Social democracy in search of a purpose. London, UK: Policy Network.

Curle, A. (1971). Making peace. London: Tavistock.

Deutsch, M, \& Coleman, P.T. (2000). The handbook of conflict resolution. theory \& practice. San Francisco, CA: Jossey-Bass publisher.

De Lucas, T. \& Buell, J. T. (2006). Free trade: A paradox for democracy: Routledge. New Political Science, 28, 4.

Deutsch, M. (1979). The prevention of World War III. A psychological perspective. Political psychology, 4, 3-31.

Doyle, M.W. (1986). Kant, liberalism and world politics. American Political Science Review, 80, 4.

European Commission (1996 a). Economic evaluation of the Single Market: European Economy: Reports \& Studies.

European Commission (2002). European Economy. Reports \& Studies.

European Commission (2004). European neighborhood policy. Strategy paper, communication from the commission, COM (2004) 373 final, Brussels, May 12.

European Commission (2006). Special Eurobarometer: Internal Market. Opinions \& experiences of the citizens in EU-25. Retrieved June 12, 2012.

European Commission: http://conventions.coe.int. Retrieved June 12, 2012 from www.erunion.org/legislate/Death Penalty/eumemorandum.hmt.

EU Institutions and other bodies (2006). Retrieved June 12, 2012 from 
http://europa.eu/institutions/decision-making/index_en.htm.

Holden, M. (2003). Stages of economic integration: From autarky to economic union. In Mirus, R. \& Ryiska, N. (2001). Economic integration: Free trade areas vs Customs union. Western Center for Economic Research, Standing committee on Foreign affairs \& international trade. Third report.

Echengreen, E. \& Boltho, A. (2008). The Economic impact of European Integration. international macroeconomics and economic history. Retrieved July 10, 2013 from www.cepr.org

European Commission (2002). Retrieved June 12, 2013 from http://conventions.coe.int; www.erunion.org/legislate/Death

European Commission (2006). Communication from the Commission to Council \& the European Parliament. Enlargement, two years after-an Economic success. Retrieved July 10, 2013 from http://ec.europa.eu/economy_finance/publicationss/occasional_papers/2006/ocp 24en.pdf

Euromove (2011). European Movement: EU Competition Policy. Retrieved July 10, 2013

from http://www.euromove.org.uk/index.php?id=6516

Europa: Europe in twelve lessons: Retrieved July 10, 2013 from http//europa.eu/abc/12lessons/lesson_l/idex_en.htm

EU Memorandum (2003). Retrieved July 10, 2013 from www.eumemorandum.org/legislate/DeathPenalty/eumemorandum.htm.

Galtung, J. (1995). Galtung, J. (1995). Global Governance for and by Global Democracy, 1, 8: Macalester International. Retrieved June 12, from http://digitalcommons.macalester.edu/macintl/vol1/iss $1 / 8$

Galtung, J. (1996). Peace by peaceful means: Peace \& conflict, development \& civilization. London, UK: Sage.

Glaeser, D. L; La Porta, R; Lopez-de-Silanes, F; Shleifer, A. (2004). Do institutions cause growth? Journal of economic growth, 9, 271-303. The Netherlands. Academic Publishers. 
Gartzke, E. (1998). The Capitalist peace: Columbia University.

Gartzke, E. \& Li, Q. (2003). Measure for measure: Concept operationalization and the trade interdependence-conflict debate. Journal of peace research, 5, 553-571.

Gartzke, E. (2005). Economic freedom \& peace: Economic freedom of the world. Annual report.

Gartzke, E. \& Hewitt, J. J. (2010). International crisis and the capitalist peace: International interactions, 36, 115-145. Routledge, Taylor \& Francis Group.

Gartzke, E. \& Lupu, Y. (2011). Economic interdependence and the First World War. International relations and the Kantian peace. Sandiego, CA: University of California.

Gladstone, P. R. (2007). Pax Mercatoria: Does economic interdependence bring peace? MIT Center for International Studies. Retrieved March 6, 2013 from web.mit.edu/cis/

Green, R; Murphy, K. \& Snyder, S. (2000). Should demographics be placed at the end or at the beginning of mailed questionnaires? An empirical answer to a persistent methodological question. Social Work Research, 24, 237-241.

Griswold, G. (1998). Peace on earth, free trade for men. Washington DC: Cato Institute. Retrieved March 6, 2013 from www.cato.org

Haas, E. B. (1985). The uniting of Europe. London, UK: Stevens \& Sons.

Hill, S. (2010). Europe's promise: Why the European way is the best hope in an insecure age. Berkley, LA: University of California Press.

Jacob, P. \& Teune, H. (1964). The Integrative process: Guideline for the analysis of the basis of political community. In Jacob, P. \& Tuscano, J. (eds.). The integration of political communities. Lippincott, PA.

Jahn, E. (1998). European Security: Which Europe should be more secure? In Karisson, $1,21$.

Johanson, J. (2007). Nonviolence: More than the absence of violence. In Jahn, E. (1988). European Security which Europe should be more secure? (p. 1-21). 
John, M. \& O’Leary, B. (2007). Politics of antagonism: Understanding Northern Ireland. Abingdon, Oxford: Routledge.

Johnson, J.B. (1998). Free trade, regionalism \& the democratic peace theory. MS thesis in political science, Portland State University. Portland, OR.

Jungblut, B. M. (1999). Economic interdependence \& interstate conflict: The influence of democratic economic interests. Paper delivered at the annual meeting of the International Studies Association, Washington DC.

Irwin, D. A. (1996). Against the ride. An intellectual history of free trade. Princeton, NJ: Princeton University press

Kant, I. (1970). Perpetual peace. Political writings (2nd ed.). Hans Reiss, (ed.). Cambridge University Press.

Kant, E. (1992). Perpetual peace \& other essays on politics, history \& morals. Trans Ted Humphrey. Hackett Publishing. Retrieved August 10, 2012 from http://www.racial.org//CAH/fab012502.html

Kaufman, E. (2009). The Return of economic nationalism. The Providence journal. Harvard Belfer center for Science \& International Affairs.

Keohane, R. (1984). After Hegemony: Princeton University Press.

Keohane, R. \& Martin, L. (1995). The promise of institutionalized theory. International Security; 20.1, 5-39.

Keohane, R. O. and Nye, J.S. (1977). Power and interdependence: World politics in transition. Boston, MA: Little, Brown.

Kindleberger, C. (1970). European integration \& the international cooperation. In Brown C. (ed.). World business. New York, NY.

Lairson, T. D; \& Skidmore,. D. (1997). International political economy. The struggle for power $\&$ wealth $\left(2^{\text {nd }}\right.$ ed.). Harcourt $\&$ Brace College. Philadelphia, PA.

Laseser, E. L; La Porta, R. A; Lopez, F. \& Shleifer, A. (2004). Do institutions cause growth? Journal of economic growth, 9, 271-303.

Federacy, J.P. (1995). Preparing for peace: Conflict transformation across cultures. New York, NY: Syracuse University Press. 
Leonard, L. (2010). Guide to the European Union. The Economist. London: Profile Books.

Leonard, M. (2005). Why Europe will run the 21st century. Public Affairs. New York, NY.

Leonard, D. (2010). European Union. The definitive guide to all aspects of the EU. The Economist. London, England: Profile Books.

Levy, L. S. (2001). War and peace, in the handbook of international relations. In Carlsnaes, W; Risse, T; and Simmons, B. (eds,). 350-367.

Lipset, S. M. (1960). Political man: The social basis of modern politics. New York. NY: Doubleday.

Lindberg, L. (1971). Political integration as a multidimensional phenomenon requiring multivariate measurement. In Lindberg \& Scheingold, (eds.). Regional integration. Theory \& research. Cambridge, Mass: Harvard University Press.

Mansfield, E. \& Pollin, B. (2003). Economic interdependence and international conflict: New Perspective in an Enduring Debate: University of Michigan Press.

McCormick, J. (2005). Understanding the European Union. A concise introduction. Palgrave: Macmillan.

McDonald, P. J. (2004). Peace through trade or free trade? Journal of conflict Resolution, 4, 547-572.

McDonald, P. J. \& Sweeny, K. (2007). The Achilles heel of liberal IR theory?: Globalization and conflict in the pre-World War I era. World politics, 59, 370-403.

McDonald, P.J. (2004). Peace through trade or free trade? Journal of conflict Resolution, 4, 547-572.

Merino, N. (2007). The European Union: Opposing viewpoints series. New York, NY: Green Heaven Press.

Moussis, N. (2011). Access to European law, economics, policies: Retrieved from http://www.Europedia.moussis.eu/books/Book_2/5/15/index.tkl?all=1\&pos-183 
Morganthan, H. I. (1964). Scientific man versus power politics. Chicago, Il: University of Chicago Press.

Moravcsik, A. (2006). Rumors of Europe's demise are greatly exaggerated. The Washington note. Retrieved August 10, 2012 from www.the washingtonnote.com/archives/001452.php

Nelsen, B.F. \& Stubb, A. (2003). The European Union: Readings on the Practice of European integration. London, UK : Lynne Riemmer.

North, D. C. (1981). Structure and change in economic history. New York. Norton \& Co.

North, D. C. (1990). Institutions, institutional change and economic performance: Cambridge University Press.

Nye, J. S. (1972). Multinational enterprises \& prospects for regional \& global integration. Annals of the American Academy of Political \& Social Science. The multinational cooperation, 403, 116-126.

Nye, J. S. (1977). Power \& interdependence. Boston, MA: Little Brown.

OECD (1996). Organization for European economic co-operation. Retrieved October 29, 2011 from www.oecd.org

Offer, A. (1989). The First World War: An agrarian interdependent. Oxford, UK: Oxford University Press, 15, 325-326.

Oneal, J. R. \& Russett, B. (1999). Assessing the liberal peace with alternative specifications, trade still reduces conflict. Journal of Peace Research, 36, 423442.

Papayoanou. (1996). Interdependence, institutions and the balance of power: Britain, Germany, and World War I. International Security, 20, 42-76.

Patten, C. (1999). The future of the European security \& defence policy (ESDP) \& the role of the European Commission. Paper presented at the conference on the development of a common European security \& defence policy in Berlin.

Polacheck, S. W. (1980). Conflict and trade. Journal of Conflict Resolution, 24, 57-78 
Polachek, S. W. (1997). Why democracies cooperate more and fight less: The relationship between international trade and cooperation. Review of International Economics, 5, 295-309.

Polacheck, S. W. \& McDonald, J. (1992). Strategic trade \& the incentive for cooperation. In disarmament, economic conversions \& the management of peace. New York, NY: Praeger.

Pinder, J. (1991). European Community. Oxford, UK: Oxford University Press.

Rachman, G. (2004). A divided union: The Economist, 4, 372-394.

Radaelli, C. (2007). Whither better regulation for the Lisbon agenda? Journal of European Public Policy, 14, 190-2007.

Resocrance, R. (1986). The Rise of the trading state: Commerce and conquest in the modern world. New York, NY: Basic Books.

Rifkin, J. (2004). The European dream: How Europe's vision of the future is quietly eclipsing the American dream. New York, NY: Jeremy P. Tarcher/Penguin.

Rips man, N. M; \& Blanchard, J. F. (1996). Commercial liberalism under fire. Evidence from 1914 \& 1936. Security Studies, 6, 4-52.

Rowe, D. M. (2005). World economic expansion and national security in pre-World War I Europe. International organization, 53, 195-231.

Rupesinghe, K. (1995). Conflict transformation. London, UK: Macmillan.

Russett, B. (1991). Esoteric evidence on democracies rarely fights each other? The Edmond James lecture, University of Illinois. In Ray, R. (1997). The democratic path to peace. Journal of Democracy, 8, 49-64.

Saving, J. L. (2005). European economic integration. Southwest Economy: Federal Reserve Bank of Dallas.

Schokking, J. J; \& Anderson, N. (1960). Observations on the European integration process. The Journal of Conflict Resolution, 4, 385-410.

Smith, A. D. (1993). Ties that bind. LSE economic \& Political Science Magazine, 5, 811 . 
Steindl, F. G. (2007). What ended the Great Depression? It was not World War II. The Independent Review, 5, 179-197.

Urwin, D. W. (1991). The Community of Europe. A history of European integration since 1945. New York, NY: Longman.

The Economist (1992). The Economic Atlas of the New Europe: A Henry Holt reference books. New York, NY: Holt and Company.

The Economist (2004). Ever expanding union. The Economist newspapers, April, 29.

Wallace, H. \& Wallace, W. (1996). Policy making in the European Union. Oxford, UK: Oxford University Press.

Ward, M. D; Siverson, R. M; \& Cao, X. (2007). Disputes, democracies, and dependencies: A re-examination of the Kantian peace. American Journal of Political Science; 51, 583-601.

Weillerstein, I. (19799). The Capitalist world economy. London, UK: Cambridge University Press. 